\title{
Highly perturbed genes and hub genes associated with type 2 diabetes in different tissues of adult humans: A bioinformatics analytic workflow
}

Kushan De Silva ${ }^{1}$, Ryan T. Demmer ${ }^{2,3}$, Daniel Jönsson ${ }^{4,5}$, Aya Mousa ${ }^{1}$, Andrew Forbes ${ }^{6}$, Joanne Enticott ${ }^{1}$

${ }^{1}$ Monash Centre for Health Research and Implementation, School of Public Health and Preventive Medicine, Faculty of Medicine, Nursing, and Health Sciences, Monash University, Clayton, 3168, Australia

${ }^{2}$ Division of Epidemiology and Community Health, School of Public Health, University of Minnesota, Minneapolis, Minnesota, USA

${ }^{3}$ Mailman School of Public Health, Columbia University, New York, USA

${ }^{4}$ Department of Periodontology, Faculty of Odontology, Malmö University, Malmö, 21119, Sweden

${ }^{5}$ Department of Clinical Sciences, Lund University, Malmö, 21428, Sweden

${ }^{6}$ Biostatistics Unit, Division of Research Methodology, School of Public Health and Preventive Medicine, Faculty of Medicine, Nursing, and Health Sciences, Monash University, Melbourne, 3004, Australia

\section{Name and contact information of the corresponding author}

Kushan De Silva

Postal Address

Locked Bag 29

Level 1, 43-51 Kanooka Grove

Clayton VIC 3168

Australia

Monash Centre for Health Research and Implementation

School of Public Health and Preventive Medicine 
Faculty of Medicine, Nursing and Health Sciences

Monash University

Australia

Email: kushan.ranakombu@monash.edu

Telephone: +61399056824

ORCID ID: $\underline{\text { 0000-0003-0301-0805 }}$

Key-words/phrases: Type 2 diabetes; Highly perturbed genes; Hub genes; Meta-analysis;

Differential gene expression; COVID-19 


\section{ABSTRACT}

Introduction: Type 2 diabetes (T2D) has a complex etiology which is not fully elucidated. Identification of gene perturbations and hub genes of T2D may assist in personalizing care.

Objectives: We aimed to identify highly perturbed genes and hub genes associated with T2D in different tissues of adult humans via an extensive workflow.

Methods: Workflow comprised five sequential steps: systematic review of NCBI GEO database; identification and classification of differentially expressed genes (DEG); identification of highly perturbed genes via meta-analysis; identification of hub genes via network analysis; downstream analyses. Three meta-analytic strategies: random effects model (REM); vote counting approach (VC); p-value combining approach (CA), were applied. Nodes having above average betweenness, closeness, and degree in the network were defined as hub genes. Downstream analyses included gene ontologies, Kyoto Encyclopedia of Genes and Genomes pathways, metabolomics, COVID-19 related genes, and Genotype-Tissue Expression profiles.

Results: Analysis of 27 eligible microarrays identified 6284 DEG (4592 down-regulated and 1692 up-regulated) within four tissue types. Tissue-specific gene expression was significantly greater than tissue non-specific (shared) gene expression. Meta-analysis of DEG identified 49, 27, and 8 highly perturbed genes via REM, VC, and CA, respectively, producing a compiled set of 79 highly perturbed (41 down-regulated and 38 up-regulated) genes. The 28 hub genes comprised 13 up-regulated, 9 down-regulated, and 6 predicted genes. Downstream analyses identified enrichments of: shared genes with other diabetes phenotypes; insulin synthesis and action related pathways and metabolomics; mechanistic associations with apoptosis and immunity-related pathways, COVID-19 related gene sets; and cell types demonstrating over- and under-expression of marker genes of T2D. 
Conclusions: We identified highly perturbed genes and hub genes of T2D and revealed their associations with other diabetes phenotypes and COVID-19 as well as pathophysiological manifestations such as those related to insulin, immunity, and apoptosis. Broader utility of the proposed pipeline is envisaged.

Keywords: Type 2 diabetes; Highly perturbed genes; Hub genes; Meta-analysis; Differential gene expression; COVID-19 


\section{INTRODUCTION}

According to an analysis of global data through years 1990-2018, diabetes was prevalent in almost half a billion people, a number expected to rise by $25 \%$ and $51 \%$, respectively, by 2030 and 2045 [1]. Type 2 diabetes (T2D) is by far the most common, accounting for over $90 \%$ of all diabetes cases [2], a condition found to have affected $6.3 \%$ (462 million) of the world population as in year 2017 [3]. Current evidence suggests a complex and multifactorial etiology of T2D characterized by genetic and environmental interactions [4], although T2D pathogenesis is not yet fully elucidated. Moreover, there is evidence of varying degrees of shared genetic origins in the pathogenesis of T2D and other diabetes phenotypes such as type 1 diabetes (T1D) [5], latent autoimmune diabetes in adults (LADA) [6], and maturity-onset diabetes of the young (MODY) [7]. Recent studies also support the deconstruction of T2D heterogeneity to define T2D sub-types [8] and the delineation of a continuum of diabetes subtypes [9] as opposed to the status quo characterized by a few distinct diabetes phenotypes. Understanding the genetic basis of $\mathrm{T} 2 \mathrm{D}$ is fundamental to precision medicine approaches striving for impeccable matching and an individualized level of T2D care [10].

Hyperglycemia in T2D is triggered by both impaired action and secretion of insulin [11], unlike T1D the hallmark of which is a lack of insulin synthesis owing to autoimmunemediated pancreatic $\beta$-cell destruction [12]. Cardinal tissues of the body impacted by heightened insulin resistance (IR) and diminished insulin secretion in T2D include the pancreas, liver, skeletal muscle, and adipose tissue [13]. Alterations in the pancreas with T2D include the deposition of $\beta$-amyloid [14], reduced $\beta$-cell mass and increased $\beta$-cell apoptosis [15], as well as decreased size, irregularities of morphology and increased fat content [16]. A salient manifestation of $\mathrm{T} 2 \mathrm{D}$ is the compromised insulin-mediated glucose uptake predominantly by skeletal muscle and to a lesser extent by adipose tissue resulting in hyperglycemia [17]. More granular findings associated with T2D such as modifications of 
skeletal muscle proteins responsible for work capacity [18] and reduction of skeletal muscle capillary density and microvascular function [19] have also been reported. Adipose tissue inflammation [20] and lipotoxicity [21] have been implicated in T2D pathogenesis. These adipose tissue changes in people with T2D may be caused by numerous transcriptional and epigenetic changes [22]. Similarly, liver fat has been implicated in the pathogenesis of T2D [23] possibly via oxidized fatty acids [24].

Exploration of gene perturbation in T2D can deepen our understanding of the molecular etiopathology of T2D. Highly up- and down-regulated genes expressed consistently across different tissue types may uncover potential genome-wide biomarkers of the disease. Identification of such gene signatures is also an integral component of precision diagnostic, prognostic, monitoring, and treatment approaches. Topologically, hub genes are defined as highly and tightly connected nodes in typically scale-free gene regulatory networks (GRN) [25]. As such, criteria such as high correlation in candidate modules [26] and above-average betweenness, closeness, and degree [27] in GRN have been used to demarcate hub genes in previous studies. Functionally, they perform critical regulatory roles in biological processes interacting with many other genes in associated pathways. Given their crucial structural and functional characteristics, hub genes are highly sought-after in precision medicine approaches as plausible niches for developing drug and treatment targets [28]. In this context, the importance of identifying highly perturbed genes and hub genes associated with T2D for the purpose of individualizing T2D care is unequivocal.

Downstream analyses of gene sets provide invaluable insights into associated core biological functions, pathways, diseases, drugs and many other aspects. Frequently used gene ontology (GO) analysis provide evidence as a snapshot of contemporary biological knowledge related to a given gene including its function at the molecular level, the cellular location(s) it functions at and the biological processes reliant on it [29]. Pathway analyses such as Kyoto 
Encyclopedia of Genes and Genomes (KEGG) [30] entail derivation of coherent and meaningful biological phenomena attributable to input genes [31]. Besides classic GO and pathway analyses, further downstream analyses such as diseases, drugs, metabolomes, and tissue enrichment are also available and can provide valuable insights into associated genes. Taken together, downstream analysis of highly perturbed- and hub genes associated with T2D may render valuable information on aspects such as affected biological processes, dysregulated pathways, related diseases, and metabolomic biomarkers.

Advances in high-throughput technologies have generated a wealth of gene expression data whilst the availability of open-source platforms such as the National Center for Biotechnology Information Gene Expression Omnibus (NCBI GEO) [32, 33] and simultaneous advent in big data and bioinformatics analytic tools such as microarray and RNA-seq meta-analysis and gene-gene interaction network analysis strategies have offered unprecedented opportunities for high-level evidence synthesis from a multitude of gene expression datasets. Such approaches are likely to render new knowledge on complex diseases like T2D and acquire adequate statistical power to identify genes associated with a disease that may not have been evoked via prior analysis of a single or a few datasets.

Yet, to date, no comprehensive evidence synthesis study has been performed to identify highly perturbed genes and hub genes associated with T2D in human adults using an extensive bioinformatics analytic pipeline. Prior studies were limited to identifying hub genes in a few $(n=3)$ microarrays from a single tissue type (pancreatic islets) [34] or performing an ad hoc gene expression meta-analysis of all diabetes phenotypes $(\mathrm{n}=13)$ [35]. In this study, we aimed to identify highly perturbed genes and hub genes associated with T2D in different tissues of adult humans via a pre-defined and extensive bioinformatics analytic workflow consisting of systematic review, meta-analysis, identification and classification of differentially expressed genes (DEG), network analysis and downstream analysis. 


\section{METHODS}

The methodological approach is summarized in S1 Figure and consisted of five sequential steps: (1) Systematic review of NCBI GEO expression data and related publications (2) Analysis of microarrays to identify DEG (3) Meta-analysis of DEG to identify highly perturbed genes in T2D (4) Network analysis of gene-gene/protein-protein interactions to identify hub genes in T2D (5) Downstream analysis of highly perturbed genes and hub genes associated with T2D.

\subsection{Systematic review}

A preliminary search on the NCBI GEO database was first run on $1^{\text {st }}$ June 2021 using a predefined search string: “("diabetes mellitus, type 2"[MeSH Terms] OR type 2 diabetes[All Fields]) AND "Homo sapiens"[porgn] AND "Expression profiling by array"[Filter]". The resulting 178 microarrays and related publications were further screened against pre-defined eligibility criteria. Microarrays of conditions other than T2D, all diabetes phenotypes other than T2D, as well as early dysglycemic conditions such as impaired glucose tolerance (IGT), insulin resistance (IR), and prediabetes were excluded. Studies with non-human specimens, children, without healthy controls or with notable co-morbidity in control samples were also excluded. We also omitted studies involving long non-coding RNA (lncRNA), micro RNA (miRNA), samples subject to drug treatments and other interventions, pluripotent stem cells, xenografts, transfected or transgenic tissues, undifferentiated tissues, and sub-samples in super-series. This resulted in 45 microarrays for manual curation which were further screened along with the full texts of related publications (where available) against eligibility criteria and for the presence of adequate information such as clinical diagnosis (healthy vs T2D), gene symbol/Entrez ID. Following this, 27 microarrays were selected for subsequent analyses, the details of which are provided in $\mathbf{S 2}$ Table. 


\subsection{Identification of DEG}

The 27 microarrays were imported to $R$ using 'getGEO' function of 'GEOquery' package [36]. In each expression set, 'phenoData' component was examined to determine the number of eligible samples and confirm the presence of outcome (T2D vs controls) variable whilst 'featureData' component was explored to verify the presence of gene annotation information. Where required, non-Normalized gene expression matrices were $\log _{2}$ transformed in order to alleviate skewness and create symmetric distributions [37]. Samples were assessed for the presence of any batch effects between the two groups by running principal components analysis on transposed expression matrices and were rectified using 'removeBatchEffect' function in 'limma' package [38]. Relevant features were annotated with expression matrices to generate curated data for running DEG analysis. Samples were ascribed to the relevant group (T2D/control) using 'model.matrix' function of 'limma' package [38] producing a binary design matrix. As the detection of DEG can be enhanced by filtering genes with a low expression level, we assumed a median (50\%) cut-off for the gene expression level. A uniform analytic pipeline consisting of the following sequential steps were applied to each of the 27 microarrays: (1) Median expression levels were calculated and those above the median were retained. (2) From the resulting genes, those expressed in more than two samples were retained while the others were removed. (3) Model fitting was performed using 'ImFit' function of 'limma' [38] to enumerate expression levels of T2D and control groups. (4) Contrasts were defined as 'T2D - control' and 'empirical Bayes' step was run to derive differential expression results (5) The DEG, defined as those with $\log _{2} \mathrm{FC}>1$ \& BenjaminiHochberg $(\mathrm{BH})$-adjusted $\mathrm{p}<0.05$ for up-regulated genes and $\log _{2} \mathrm{FC}<-0.5 \& \mathrm{BH}$-adjusted $\mathrm{p}$ $<0.05$ for down-regulated genes, were identified for each microarray.

The number of DEG identified by each dataset is shown in Table 1. Microarrays with no DEG $(n=11)$ were excluded and those with non-zero DEG $(n=16)$ were visualized with a 
stacked bar chart (Figure 1). Finally, DEG were classified by tissue types $(n=4$; circulatory/ adipose/ digestive/ skeletal muscle) and visualized via a Venn diagram (Figure 2). Clinical and other information of the 16 microarrays with non-zero DEG is presented in S3 Table. Details of DEG identified by each dataset are presented in S4 Table, while DEG classified by tissue type are presented in S5 Table.

\subsection{Meta-analysis of DEG: Identification of highly perturbed genes}

In order to identify highly perturbed genes associated with $\mathrm{T} 2 \mathrm{D}$, we conducted meta-analysis of DEG using 'MetaVolcanoR' package [39]. We implemented all 3 meta-analytic strategies incorporated in this package, namely, random effects model (REM), vote counting approach (VC) and p-value combining approach (CA).

In brief, REM synthesizes a summary fold change of multiple microarrays based on variance, producing a summary p-value which indicates the probability that the summary fold-change is not different to zero. The 'metathr' parameter can be specified to filter the desired percentage of the top-most consistently perturbed genes. Gene perturbation is ranked as per the 'topconfects' approach [40]. The VC algorithm produces DEG according to user-specified $p$-values and fold change cut-off levels, taking into account both the number of studies in which a DEG appeared and its gene fold change sign consistency. Here also, 'metathr' parameter can be defined to extract the required percentage of highly perturbed genes. Metasynthesis of gene perturbation by CA algorithm is at the mean or median level along with pvalues derived by Fisher method. A required proportion of top-most DEG can be identified by specifying 'metathr' parameter with CA as well [39].

As required by the package, the 16 datasets each consisting of the columns: gene name (Symbol), fold change $\left(\log _{2} \mathrm{FC}\right), \mathrm{p}$-value, and confidence intervals of the fold change (CI.L \& CI.R) were merged to build a list item. For all 3 meta-analytic models, 'metathr' was set at 
0.01. For VC, p-value and absolute fold change thresholds were set at 0.05 and 0 , respectively. Highly perturbed genes identified by each model as well as the compiled list of all highly perturbed genes $(\mathrm{n}=79)$ is presented in Table $\mathbf{2}$. Volcano plots illustrating the topmost perturbed genes identified by REM, VC, and CA are given in Figures $\mathbf{3}$ - 5, respectively. Inverse cumulative distribution of consistently differentially expressed genes as per VC was plotted (Figure 6) to demonstrate the number of genes with perturbed expression in $\geq 1$ studies. We present detailed meta-analytic output from all 3 approaches in S6 Table and highly perturbed genes identified by each method in S7 Table.

\subsection{Network analysis: Identification of hub genes}

The list of highly perturbed genes $(\mathrm{n}=79)$ was fed into GENEMANIA [41] to determine the gene-gene interactions network. The interactions network formulated by the GENEMANIA gene function prediction program, based on the Multiple Association Network Integration Algorithm (MANIA), incorporates a multitude of functional associations including coexpression, pathways, physical interactions, co-localization, genetic interactions, and protein domain similarity. It has been found more accurate and computationally-efficient than other gene function prediction methods [42, 43]. The gene-gene interactions network was visualized in GENEMANIA (Figure 7) while the details of the constructed network were given in S8 Table. Next, these interactions were imported to visualize the protein-protein interaction (PPI) network (Figure 8) in STRING version 11.0 [44]. We used the 'Centiscape' application [45] in the 'Cytoscape' software [46] to analyze the PPI network and determine the hub nodes. After removing nodes with a connection number $<2$, the network was visualized in 'Cytoscape' (Figure 9). Hub genes were defined as those nodes in the network with betweenness, closeness, and degree higher than their mean values. A similar approach has been used in previous studies to demarcate hub genes [27]. Topological features of the 28 
hub nodes are summarized in Table 3 while details of the PPI network derived by 'Centiscape' are provided in $\mathbf{S 9}$ Table.

\subsection{Downstream analysis of highly perturbed genes and hub genes}

Using 'Enrichr' [47-49] platform, we ran a series of downstream analyses for both highly perturbed genes $(n=79)$ and hub genes $(n=28)$ as outlined below.

- Ontologies: GO Biological Process 2018 [29]

- Pathways: KEGG 2019 Human [30]

- Diseases/Drugs: COVID-19 Related Gene Sets

- Cell Types: GTEx Tissue Sample Gene Expression Profiles Up \& GTEx Tissue Sample Gene Expression Profiles Down

- Miscellaneous: HMDB Metabolites

The Genotype-Tissue Expression (GTEx) portal contains tissue-specific gene expression and regulation data [50], whereas the Human Metabolome Database (HMDB) records human metabolomics data [51]. Findings from downstream analyses of highly perturbed genes are summarized in Tables 4 - 6 and illustrated in Figures 10 - 12 while details given in S10 Table. Results from downstream analyses of hub genes are presented in Tables 7 - 9 and visualized in Figures 13 - 15 with details in S11 Table.

\section{RESULTS}

\subsection{A significantly larger proportion of genes associated with T2D is down- regulated.}

Of all the DEG identified by different tissues $(n=6284)$, the proportion of down-regulated genes $(n=4592)$ were significantly higher than the proportion of upregulated genes $(n=$ 1692) $(p<0.00000001)$. At the level of tissue type, circulatory (255 down-regulated vs 94 
up-regulated; $\mathrm{p}<0.000001$ ), adipose (1426 down-regulated vs 1212 up-regulated; $\mathrm{p}=$ $0.000017)$ and digestive (2664 down-regulated vs 135 up-regulated; $p<0.000001)$ tissues revealed a similar pattern while skeletal muscle (247 down-regulated vs 251 up-regulated; p $=0.44653$ ) showed no such over-expression of down-regulated genes. Of the 27 microarrays, 11 contained no DEG while the two datasets containing the highest number of DEG were from pancreatic islets (GSE25724; 2164 DEG) and visceral adipose tissue (GSE29231; 1655 DEG) (Table 1, Figure 1).

\subsection{Tissue-specific DEG are predominant compared to DEG shared between tissues in T2D.}

Proportions of tissue-specific DEG were significantly higher than the proportions shared with one or more other tissue types in circulatory (242 specific vs 89 non-specific; $p<0.000001$ ), adipose (1989 specific vs 342 non-specific; $\mathrm{p}<0.000001$ ), and digestive (1875 specific vs 409 non-specific; $\mathrm{p}<0.000001)$ groups, while skeletal muscle (244 specific vs 217 nonspecific; $p=0.112959$ ) had no such over-expression (Figure 2).

\subsection{Highly perturbed genes associated with T2D comprise both up- and down- regulated genes.}

There was no significant difference $(p=0.410983)$ between the proportions of up- $(38 / 79)$ and down-regulated (41/79) genes that constituted the highly perturbed gene set $(n=79)$ identified by all 3 meta-analytic algorithms (Table 2, Figures 3 - 6). The 38 up-regulated genes were: XYLT1, ISLR, CRTAC1, ERAP2, PCOLCE2, VNN2, U2AF2, NPTX2, MMP9, LOC100008589, DYRK3, LOC649456, BCL3, ZNF423, SOD3, CNTFR, ZNF75, RNF19B, TNFAIP6, TAPBP, PHACTR3, PHLDA1, ALDOB, PRIMA1, PVRL2, CNTNAP2, RASL11B, POMZP3, ELFN1, ESPNL, PI3, SCN1B, EGR2, MGRN1, SLC9A3R2, LOC644422, MCL1, and ZBTB16. The 41 down-regulated genes were: LOC650885, 
UGT2B7, C19orf33, HLA-DRB4, OR8B12, HLA-DRB5, IFNA7, LOC389286, FUT11, APOL4, LOC731682, KIAA1984, POPDC3, TAP2, CTSC, DYRK2, MCOLN3, TMEM37, API5, ARG2, C14orf132, COG2, DHRS2, ENPP2, ENTPD3, HADH, KIAA1279, LARP4, MARK1, MTRR, NAALAD2, PAAF1, PPM1K, PPP1R1A, RPL14, SLC2A2, SNAP25, STMN2, NMNAT2, ASCL2, and IAPP.

\subsection{Hub genes associated with T2D also comprise both up- and down-regulated genes.}

The 28 hub genes consisted of 13 up-regulated, 9 down-regulated and 6 predicted genes. There was no significant difference $(p=0.261216)$ between the proportions of up- $(13 / 22)$ and down-regulated (9/22) genes constituting the hub gene set. The 13 up-regulated hub genes were: PHLDA1, ZBTB16, SOD3, ISLR, SCN1B, MMP9, MCL1, CNTNAP2, ZNF423, CNTFR, TNFAIP6, XYLT1, and RASL11B. The 9 down-regulated genes were: CTSC, HADH, RPL14, SNAP25, SLC2A2, ENPP2, STMN2, PPP1R1A, and UGT2B7. The 6 hub genes predicted by GENEMANIA were: TAP1, DPEP1, PPP1R15A, ZMIZ1, ARG1, and CD226 (Table 3).

\subsection{Enriched biological processes associated with highly perturbed genes and hub genes of T2D.}

Ontology analysis of highly perturbed genes identified 89 enriched biological processes (S10 Table). Top 10 enriched biological processes were: Intrinsic apoptotic signaling pathway in response to DNA damage (GO:0008630); Intrinsic apoptotic signaling pathway in response to DNA damage by p53 class mediator (GO:0042771); Antigen processing and presentation of peptide antigen via MHC class I (GO:0002474); Cellular response to oxidative stress (GO:0034599); Plasma membrane bounded cell projection organization (GO:0120036); Intrinsic apoptotic signaling pathway by p53 class mediator (GO:0072332); Myeloid cell 
differentiation (GO:0030099); Nicotinamide nucleotide metabolic process (GO:0046496); Regulation of intrinsic apoptotic signaling pathway (GO:2001242); and Myeloid leukocyte differentiation (GO:0002573). Three of these: Antigen processing and presentation of peptide antigen via MHC class I (GO:0002474); Myeloid cell differentiation (GO:0030099); and Regulation of intrinsic apoptotic signaling pathway (GO:2001242) were associated with upregulated genes in T2D (Table 4).

Ontological analysis of hub genes identified 179 enriched biological processes (S11 Table). Top 10 enriched biological processes were: Neutrophil degranulation (GO:0043312); Neutrophil activation involved in immune response (GO:0002283); Neutrophil mediated immunity (GO:0002446); Regulation of intrinsic apoptotic signaling pathway (GO:2001242); Negative regulation of intrinsic apoptotic signaling pathway (GO:2001243); Positive regulation of cell projection organization (GO:0031346); Cellular response to reactive oxygen species (GO:0034614); Negative regulation of apoptotic signaling pathway (GO:2001234); Negative regulation of cysteine-type endopeptidase activity involved in apoptotic process (GO:0043154); and Regulation of peptide hormone secretion (GO:0090276). Of these, three [Regulation of intrinsic apoptotic signaling pathway (GO:2001242); Negative regulation of intrinsic apoptotic signaling pathway (GO:2001243); Negative regulation of apoptotic signalling pathway (GO:2001234)] were associated with upregulated genes in T2D whereas one [Regulation of peptide hormone secretion (GO:0090276)] was associated with down-regulated genes in T2D (Table 7).

\subsection{Enriched KEGG pathways associated with highly perturbed genes and hub genes of T2D.}

As per KEGG analysis of highly perturbed genes, 21 pathways were enriched (S10 Table). The top 10 pathways were: Epstein-Barr virus infection; Antigen processing and presentation; 
Autoimmune thyroid disease; Maturity onset diabetes of the young; Asthma; Allograft rejection; Graft-versus-host disease; Type 1 diabetes mellitus; Intestinal immune network for IgA production; and Cell adhesion molecules (CAMs). Seven of these [Autoimmune thyroid disease; Maturity onset diabetes of the young; Asthma; Allograft rejection; Graft-versus-host disease; Type 1 diabetes mellitus; Intestinal immune network for IgA production] were associated with down-regulated genes in T2D (Table 4).

According to KEGG analysis of hub genes, 12 pathways were enriched (S11 Table). The top 10 pathways were: Insulin secretion; Apoptosis; Adrenergic signaling in cardiomyocytes; Cell adhesion molecules (CAMs); JAK-STAT signaling pathway; Transcriptional misregulation in cancer; Arginine biosynthesis; Maturity onset diabetes of the young; Ascorbate and aldarate metabolism; and Fatty acid elongation. Four of these [Insulin secretion; Maturity onset diabetes of the young; Ascorbate and aldarate metabolism; Fatty acid elongation] were associated with down-regulated genes in T2D while two pathways [JAK-STAT signaling pathway and Transcriptional mis-regulation in cancer] were associated with up-regulated genes in T2D (Table 7).

\subsection{COVID-19 related gene sets associated with highly perturbed genes and hub} genes of T2D.

Downstream analyses revealed 20 COVID-19 related gene sets associated with the highly perturbed genes of T2D (S10 Table) and the top 10 of these are visualized in Figure 11 (a). There were 23 COVID-19 related gene sets associated with the hub genes of T2D (S11 Table), the top 10 of which are visualized in Figure 14 (a).

3.8. HMDB metabolites associated with highly perturbed genes and hub genes of T2D. 
Four HMDB metabolites [Zinc (HMDB01303), Manganese (HMDB01333), Magnesium (HMDB00547), C10H13N2O7P (HMDB01570)] were associated with the highly perturbed genes of T2D (S10 Table). Of these, Zinc (HMDB01303) was associated with up-regulated genes in T2D while C10H13N2O7P (HMDB01570) was associated with down-regulated genes in T2D (Table 5).

There were 45 HMDB Metabolites associated with the hub genes of T2D (S11 Table). The top 10 metabolites were: Zinc (HMDB01303); Ethyl glucuronide (HMDB10325); 3Acetoacetyl-CoA (HMDB01484); (S)-Methylmalonate semialdehyde (HMDB02217); C18H31NO14S (HMDB00632); Ornithine (HMDB00214); C24H32O8 (HMDB06224); C24H32O9 (HMDB10354); 11beta,18-Epoxy-18,21-dihydroxy-20-oxo-5beta-pregnan3alpha-yl beta-D-glucopyranosiduronic acid (HMDB10357) and C25H40O8 (HMDB10359). Seven of these [Ethyl glucuronide (HMDB10325); 3-Acetoacetyl-CoA (HMDB01484); (S)Methylmalonate semialdehyde (HMDB02217); C24H32O8 (HMDB06224); C24H32O9 (HMDB 10354); C25H40O8 (HMDB10359)] and 11beta,18-Epoxy-18,21-dihydroxy-20-oxo5beta-pregnan-3alpha-yl beta-D-glucopyranosiduronic acid (HMDB10357) were associated with down-regulated genes in T2D. One metabolite [C18H31NO14S (HMDB00632)] was associated with upregulated genes of T2D (Table 8).

\subsection{Gene expression in different cell types associated with highly perturbed genes and hub genes of T2D.}

There were 168 down-regulated GTEx profiles (S10 Table) associated with highly perturbed genes of T2D, the top 10 of which consisted of one brain, two thyroid, and seven blood tissue samples (Table 6 \& Figure 12). There were 77 up-regulated GTEx profiles (S10 Table) associated with highly perturbed genes of T2D, the top 10 of which consisted of six adiposeand one each of lung, breast, heart, and blood vessel tissue samples (Table 6 \& Figure 12). 
There were 223 down-regulated GTEx profiles (S11 Table) associated with hub genes of $\mathrm{T} 2 \mathrm{D}$, the top 10 of which consisted of five nervous system (three brain, one nerve, one pituitary), three blood, one breast and one bladder tissue samples (Table 9 \& Figure 15). There were 178 up-regulated GTEx profiles (S11 Table) associated with hub genes of T2D, the top 10 of which consisted of six adipose-, two blood and two skin tissue samples (Table 9

\section{\& Figure 15).}

\section{DISCUSSION}

In this study, we identified highly perturbed genes and hub genes associated with T2D in different tissues of adult humans, via an extensive bioinformatics analytic workflow. By doing this, we revealed valuable insights with respect to T2D pathogenesis, including associations with other diabetes phenotypes and COVID-19, patterns of tissue-specific and tissue non-specific differential gene expression as well as pathophysiological manifestations such as those related to insulin action, immunity, and apoptosis. Salient findings of the study which contribute towards the understanding of the genetic basis of T2D are further discussed below. The comprehensive evidence synthesis approach with open-source gene expression data exemplified in this study can be replicated to gain high-level evidence synthesis for other clinical conditions.

\subsection{Patterns of differential gene expression in T2D}

Our findings indicate that T2D seems rather a disorder of gene down-regulation than upregulation, when the whole genome is considered. This is consistent with previous studies where a preponderance of gene down-regulation was associated with T2D $(52,53)$. Also, hyperglycemia-induced global downregulation of gene expression in adipose and skeletal muscle tissues have been documented previously (54). A similar pattern has been observed in T1D (55) as well as other endocrine disorders such as polycystic ovary syndrome (56). In 
contrast, highly perturbed genes and hub genes associated with T2D, which might together constitute the candidate gene set critical for pathogenicity of T2D, were found to contain both up- and down-regulated genes. This presentation suggests a more complex dysregulation at the crux of the GRN of T2D, involving actions and interactions between both repressed and augmented genes.

\subsection{Tissue-specific and tissue non-specific DEG associated with T2D}

Results of the present study indicate the predominance of tissue-specific DEG in T2D which may have important implications for guiding biomarker discovery process. It supports the use of target tissue gene expression analysis as a viable avenue for identifying tissue-specific T2D biomarkers. A previous analysis integrating multiple tissue transcriptomics and PPI data to explore molecular biomarkers of T2D confirmed the presence of common signatures (57). We also observed common DEG across different tissue types which can act as confluent molecular signatures of T2D. Identification of tissue-specific and non-specific molecular gene signatures of T2D facilitates downstream exploration of key pathways amenable to therapeutic targeting and drug repurposing efforts.

\subsection{Shared gene enrichment across diabetes phenotypes}

As revealed by KEGG pathway analyses, both MODY and T1D were enriched pathways associated with highly perturbed genes of T2D. In addition, MODY was an enriched pathway associated with hub genes of T2D as well. Specifically, SLC2A2 (GLUT2) and IAPP genes were commonly enriched in MODY, while HLA-DRB4 and HLA-DRB5 genes were underlying the enrichment with T1D. A gene expression meta-analysis also revealed the existence of possible pleiotropic mechanisms manifest via common gene signatures (PGRMC1 and HADH) across different diabetes phenotypes [35]. 
Down-regulation of SLC2A2 is associated with not only T2D [58] but also neonatal diabetes [59] and early childhood diabetes [60] suggesting a likely role in insulin secretion. Amylin (IAPP), a gluco-modulatory hormone co-expressed with insulin by pancreatic $\beta$ cells, is down-regulated in both T1D and advanced T2D [61] while amylin agonists are considered as novel therapeutic agents for treating diabetes [62]. It has also been found that human amylin plays a protective role against autoimmune diabetes inducing CD4+Foxp3+ regulatory $\mathrm{T}$ cells [63]. Downregulation of HLA-DRB4 in peripheral blood mononuclear cells (PBMC) is associated with T2D as well as dyslipidemia and periodontitis [64], while a meta-analysis revealed that the lack of HLA-DRB5 increased T2D risk [65]. Intriguingly, both HLA-DRB4 and HLA-DRB5 are associated with $\beta$ cell autoantibodies and T1D [66]. In fact, previous studies reported that both T1D and T2D share HLA class II locus components [65]. Interestingly, two of the hub genes of T2D found in our study (MMP9, ARG1) have been found as hub genes of T1D in a previous analysis [67]. Collectively, these findings support some degree of shared genetic architecture between T2D and other diabetes pathologies.

\subsection{T2D as a disorder of insulin secretion and action}

Downstream analyses provided insights into the characterization of T2D as a disorder of insulin secretion and action. We found that insulin secretion was the most significant KEGG pathway associated with hub genes, whereby two down-regulated hub genes (SLC2A2, SNAP25) in T2D were underlying this enrichment. Zinc, the most significant HMDB metabolite associated with both highly perturbed genes and hub genes of T2D, is an essential element with key regulatory roles in insulin synthesis, storage, and secretion [68]. Other metabolomic biomarkers associated with highly perturbed genes included magnesium which is necessary for insulin signaling [69] as well as manganese which is involved in insulin synthesis and secretion [70]. Together, these findings underscore the effects on insulin production and action as pivotal to T2D pathogenesis. 


\subsection{Pathophysiological manifestations of T2D}

\subsubsection{Apoptosis}

Downstream analyses revealed that multiple GO and KEGG pathways associated with apoptosis, including intrinsic apoptotic signaling pathway, were enriched in T2D. It is known that hyperglycemia-induced $\beta$ cell apoptosis, a hallmark in T2D progression, occurs via intrinsic pathways causing reduced islet mass and metabolic abnormalities [71]. Hyperglycemia-induced apoptosis has been reported to occur in other sites such as renal cells [72] and coronary arteries [73], indicating a possible role in disease progression and the onset of complications.

\subsubsection{Immunity}

Downstream analyses also revealed that multiple immunity-related GO and KEGG pathways, encompassing both innate and humoral immune responses, were enriched in T2D. These included multiple ontologies involving neutrophils, antigen processing and presentation as well as severe immune reactions such as graft-versus-host disease and allograft rejection. Impaired immunity in $\mathrm{T} 2 \mathrm{D}$ and consequent susceptibility to infections and complications is frequently observed [74]. A deeper understanding of the genomics underlying impaired immunity in T2D might provide opportunities to personalize the management of comorbidities and pharmacotherapy.

\subsection{COVID-19 and T2D}

Epidemiological studies strongly suggest poorer prognosis of COVID-19 among people with T2D [75], although underlying mechanisms are not well-understood [76]. Downstream analysis of highly perturbed genes and hub genes of T2D in the present study revealed a large number of enriched COVID-19 related gene sets, providing support for this putative link at a more granular level. 


\subsection{Over- and under- expression of genes in different tissues associated with T2D}

Downstream analysis of GTEx profiles identified tissues that are likely to demonstrate underand over-expression of DEG associated with T2D. Findings indicate that adipose tissue tends to over-express marker genes of $\mathrm{T} 2 \mathrm{D}$, while these might be under-expressed in other tissues such as those of the nervous system. These findings have implications for biomarker discovery and can guide further research on tissues which should be explored for DEG identification.

\section{CONCLUSIONS}

Taken together, these findings contribute towards the understanding of the genetic basis of T2D, which is fundamental for precision medicine approaches for individualized T2D care. Further research is warranted to explore and substantiate the molecular mechanisms underlying these findings which would be critical for establishing precision T2D medicine initiatives. The proposed bioinformatics pipeline may have broader use as a judicious strategy to identify gene perturbations and pathophysiological mechanisms of other clinical conditions beyond T2D which ought to be validated in future research. Finally, this study describes an exemplary approach to applying comprehensive evidence synthesis using existing open source gene expression data. Other researchers are encouraged to apply this methodology to obtain high-level evidence from existing multiple datasets thereby getting the most value from existing bioinformatics sources.

\section{ACKNOWLEDGEMENTS INCLUDING DECLARATIONS}

Ethics approval: Not required being a review and secondary analysis of publicly available, deidentified data.

Funding: KDS is supported by a PhD scholarship funded by the Australian Government under Research Training Program (RTP). 
Role of the Funder/Sponsor: The funder was not involved in the design of the study; the collection, analysis, and interpretation of data; writing the report; and did not impose any restrictions regarding the publication of the report.

Conflicts of interest statement: Authors declare that there are no conflicts of interest.

Author contributions: KDS performed data acquisition, pre-processing and curation of data, conducted the analyses and wrote this manuscript. KDS, RTD, AF and JE were responsible for study conceptualization and design, contributed to validating analyses, results and interpretation, and drafting the manuscript. DJ and AM contributed to study conceptualization and design, interpretation of data and critically revised the manuscript for important intellectual content.

Availability of data and material: Data used in this study are freely available at the National Center for Biotechnology Information Gene Expression Omnibus (NCBI GEO) portal: https://www.ncbi.nlm.nih.gov/geo/

Code availability: All analytic codes are available on reasonable request from the corresponding author.

\section{REFERENCES}

1. Saeedi P, Petersohn I, Salpea P, Malanda B, Karuranga S, Unwin N, et al. Global and regional diabetes prevalence estimates for 2019 and projections for 2030 and 2045: Results from the International Diabetes Federation Diabetes Atlas, 9th edition. Diabetes Clin Res $\quad$ Rest. 2019;157:107843. https://doi.org/10.1016/j.diabres.2019.107843

2. Zheng Y, Ley SH, Hu FB. Global aetiology and epidemiology of type 2 diabetes mellitus and its complications. Nat Rev Endocrinol. 2018;14(2):88-98. DOI: 10.1038/nrendo.2017.151. 
3. Khan MAB, Hashim MJ, King JK, Govender RD, Mustafa H, Al Kaabi J. Epidemiology of type 2 diabetes-global burden of disease and forecasted trends. $J$ Epidemiol Health. 2020;10(1):107-111. https://doi.org/10.2991/jegh.k.191028.001

4. Arroyo MN, Green JA, Cnop M, Igoillo-Esteve M. tRNA Biology in the Pathogenesis of Diabetes: Role of Genetic and Environmental Factors. Int $\mathrm{J}$ Mol Sci. 2021;22(2):496. https://doi.org/10.3390/ijms22020496

5. Aylward A, Chiou J, Okino ML, Kadakia N, Gaulton KJ. Shared genetic risk contributes to type 1 and type 2 diabetes etiology. Hum Mol Genet. 2018:ddy314. https://doi.org/10.1093/hmg/ddy314

6. Basile KJ, Guy VC, Schwartz S, Grant SF. Overlap of genetic susceptibility to type 1 diabetes, type 2 diabetes, and latent autoimmune diabetes in adults. Curr Diab Rep. 2014;14(11):550. https://doi.org/10.1007/s11892-014-0550-9

7. Bonnefond A, Boissel M, Bolze A, Durand E, Toussaint B, Vaillant E, et al. Pathogenic variants in actionable MODY genes are associated with type 2 diabetes. Nat Metab. 2020;2(10):1126-1134. https://doi.org/10.1038/s42255-020-00294-3

8. Udler MS, Kim J, von Grotthuss M, Bonàs-Guarch S, Cole JB, Chiou J et al. Type 2 diabetes genetic loci informed by multi-trait associations point to disease mechanisms and subtypes: A soft clustering analysis. PLoS Med. 2018;15(9):e1002654. https://doi.org/10.1371/journal.pmed.1002654

9. Flannick J, Johansson S, Njølstad PR. Common and rare forms of diabetes mellitus: towards a continuum of diabetes subtypes. Nat Rev Endocrinol. 2016;12(7):394-406. https://doi.org/10.1038/nrendo.2016.50

10. Prasad RB, Groop L. Precision medicine in type 2 diabetes. J Intern Med. 2019;285(1):40-48. https://doi.org/10.1111/joim.12859 
11. Campbell JE, Newgard CB. Mechanisms controlling pancreatic islet cell function in insulin secretion. Nat Rev Mol Cell Biol. 2021;22(2):142-158. https://doi.org/10.1038/s41580-020-00317-7

12. Fousteri G, Rodrigues EM, Giamporcaro GM, Falcone M. A machine learning approach to predict response to immunotherapy in type 1 diabetes. Cell Mol Immunol. 2021;18(3):515-517. https://doi.org/10.1038/s41423-020-00594-4

13. Batista TM, Haider N, Kahn CR. Defining the underlying defect in insulin action in type 2 diabetes. Diabetologia. 2021;64(5):994-1006. https://doi.org/10.1007/s00125$\underline{021-05415-5}$

14. Reza MI, Syed AA, Kumariya S, Singh P, Husain A, Gayen JR. Pancreastatin induces islet amyloid peptide aggregation in the pancreas, liver, and skeletal muscle: An implication for type 2 diabetes. Int J Biol Macromol. 2021;182:760-771. https://doi.org/10.1016/j.ijbiomac.2021.04.064

15. McKimpson WM, Chen Y, Irving JA, Zheng M, Weinberger J, Tan WLW, et al. Conversion of the death inhibitor ARC to a killer activates pancreatic $\beta$ cell death in diabetes. Dev Cell. 2021;56(6):747-760.e6. https://doi.org/10.1016/j.devcel.2021.02.011

16. Macauley M, Percival K, Thelwall PE, Hollingsworth KG, Taylor R. Altered volume, morphology and composition of the pancreas in type 2 diabetes. PLoS One. 2015;10(5):e0126825. https://doi.org/10.1371/journal.pone.0126825

17. Chadt A, Al-Hasani H. Glucose transporters in adipose tissue, liver, and skeletal muscle in metabolic health and disease. Pflugers Arch. 2020;472(9):1273-1298. https://doi.org/10.1007/s00424-020-02417-X 
18. Baasch-Skytte T, Gunnarsson TP, Fiorenza M, Bangsbo J. Skeletal muscle proteins important for work capacity are altered with type 2 diabetes - Effect of 10-20-30 training. Physiol Rep. 2021;9(1):e14681. https://doi.org/10.14814/phy2.14681

19. Groen BB, Hamer HM, Snijders T, van Kranenburg J, Frijns D, Vink H, et al. Skeletal muscle capillary density and microvascular function are compromised with aging and type 2 diabetes. $J$ Appl Physiol. 2014;116(8):998-1005. https://doi.org/10.1152/japplphysiol.00919.2013

20. Kohlgruber A, Lynch L. Adipose tissue inflammation in the pathogenesis of type 2 diabetes. Curr Diab Rep. 2015;15(11):92. https://doi.org/10.1007/s11892-015-0670-x

21. Meex RCR, Blaak EE, van Loon LJC. Lipotoxicity plays a key role in the development of both insulin resistance and muscle atrophy in patients with type 2 diabetes. Obes Rev. 2019;20(9):1205-1217. https://doi.org/10.1111/obr.12862

22. Nilsson E, Jansson PA, Perfilyev A, Volkov P, Pedersen M, Svensson MK, et al. Altered DNA methylation and differential expression of genes influencing metabolism and inflammation in adipose tissue from subjects with type 2 diabetes. Diabetes. 2014;63(9):2962-2976. https://doi.org/10.2337/db13-1459

23. Stols-Gonçalves D, Tristão LS, Henneman P, Nieuwdorp M. Epigenetic Markers and Microbiota/Metabolite-Induced Epigenetic Modifications in the Pathogenesis of Obesity, Metabolic Syndrome, Type 2 Diabetes, and Non-alcoholic Fatty Liver Disease. Curr Diab Rep. 2019;19(6):31. https://doi.org/10.1007/s11892-019-1151-4

24. Santoro N, Caprio S, Giannini C, Kim G, Kursawe R, Pierpont B, et al. Oxidized fatty acids: A potential pathogenic link between fatty liver and type 2 diabetes in obese adolescents? Antioxid Redox Signal. 2014;20(2):383-389. https://doi.org/10.1089/ars.2013.5466 
25. Buchberger E, Bilen A, Ayaz S, Salamanca D, Matas de Las Heras C, Niksic A, et al. Variation in pleiotropic hub gene expression is associated with interspecific differences in head shape and eye size in Drosophila. Mol Biol Evol. 2021:msaa335. https://doi.org/10.1093/molbev/msaa335

26. Liu Y, Gu HY, Zhu J, Niu YM, Zhang C, Guo GL. Identification of Hub Genes and Key Pathways Associated With Bipolar Disorder Based on Weighted Gene Coexpression Network Analysis. Front Physiol. 2019;10:1081. https://doi.org/10.3389/fphys.2019.01081

27. Liu Y, Yi Y, Wu W, Wu K, Zhang W. Bioinformatics prediction and analysis of hub genes and pathways of three types of gynecological cancer. Oncol Lett. 2019;18(1):617-628. https://doi.org/10.3892/ol.2019.10371

28. Liu H, Qu Y, Zhou H, Zheng Z, Zhao J, Zhang J. Bioinformatic analysis of potential hub genes in gastric adenocarcinoma. Sci Prog. 2021;104(1):368504211004260. https://doi.org/10.1177/00368504211004260

29. Hill DP, Smith B, McAndrews-Hill MS, Blake JA. Gene Ontology annotations: what they mean and where they come from. BMC Bioinformatics. 2008;9 Suppl 5(Suppl 5):S2. https://doi.org/10.1186/1471-2105-9-S5-S2

30. Kanehisa M, Goto S. KEGG: kyoto encyclopedia of genes and genomes. Nucleic Acids Res. 2000;28(1):27-30. https://doi.org/10.1093/nar/28.1.27

31. Nguyen TM, Shafi A, Nguyen T, Draghici S. Identifying significantly impacted pathways: a comprehensive review and assessment. Genome Biol. 2019;20(1):203. https://doi.org/10.1186/s13059-019-1790-4

32. Edgar R, Domrachev M, Lash AE. Gene Expression Omnibus: NCBI gene expression and hybridization array data repository. Nucleic Acids Res. 2002;30(1):207-210. https://doi.org/10.1093/nar/30.1.207 
33. Barrett T, Wilhite SE, Ledoux P, Evangelista C, Kim IF, Tomashevsky M, et al. NCBI GEO: archive for functional genomics data sets--update. Nucleic Acids Res. 2013;41(Database issue):D991-5. https://doi.org/10.1093/nar/gks1193

34. Lin Y, Li J, Wu D, Wang F, Fang Z, Shen G. Identification of Hub Genes in Type 2 Diabetes Mellitus Using Bioinformatics Analysis. Diabetes Metab Syndr Obes. 2020;13:1793-1801. https://doi.org/10.2147/DMSO.S245165

35. Mei H, Li L, Liu S, Jiang F, Griswold M, Mosley T. Tissue Non-Specific Genes and Pathways Associated with Diabetes: An Expression Meta-Analysis. Genes (Basel). 2017;8(1):44. https://doi.org/10.3390/genes8010044

36. Davis S, Meltzer PS. GEOquery: a bridge between the Gene Expression Omnibus (GEO) and BioConductor. Bioinformatics. 2007;23(14):1846-7. https://doi.org/10.1093/bioinformatics/btm254

37. Le NQ, Do DT, Nguyen NT, Hung TN, Trang NT. Identification of gene expression signatures for psoriasis classification using machine learning techniques. Medicine in Omics. 2020;1:100001. https://doi.org/10.1016/j.meomic.2020.100001

38. Ritchie ME, Phipson B, Wu D, Hu Y, Law CW, Shi W, et al. limma powers differential expression analyses for RNA-sequencing and microarray studies. Nucleic Acids Res. 2015;43(7):e47. https://doi.org/10.1093/nar/gkv007

39. Prada C, Lima D, Nakaya H. MetaVolcanoR: Gene Expression Meta-analysis Visualization Tool. R package version 1.4.0. 2020.

40. Harrison PF, Pattison AD, Powell DR, Beilharz TH. Topconfects: a package for confident effect sizes in differential expression analysis provides a more biologically useful ranked gene list. Genome Biol. 2019;20(1):67. https://doi.org/10.1186/s13059$\underline{019-1674-7}$ 
41. Warde-Farley D, Donaldson SL, Comes O, Zuberi K, Badrawi R, Chao P, et al. The GeneMANIA prediction server: biological network integration for gene prioritization and predicting gene function. Nucleic Acids Res. 2010;38(Web Server issue):W21420. https://doi.org/10.1093/nar/gkq537

42. Mostafavi S, Ray D, Warde-Farley D, Grouios C, Morris Q. GeneMANIA: a realtime multiple association network integration algorithm for predicting gene function. Genome Biol. 2008;9 Suppl 1(Suppl 1):S4. https://doi.org/10.1186/gb-2008-9-s1-s4

43. Peña-Castillo L, Tasan M, Myers CL, Lee H, Joshi T, Zhang C, et al. A critical assessment of Mus musculus gene function prediction using integrated genomic evidence. Genome Biol. 2008;9 Suppl 1(Suppl 1):S2. https://doi.org/10.1186/gb-20089-s1-s2

44. Szklarczyk D, Gable AL, Lyon D, Junge A, Wyder S, Huerta-Cepas J, et al. STRING v11: protein-protein association networks with increased coverage, supporting functional discovery in genome-wide experimental datasets. Nucleic Acids Res. 2019;47(D1):D607-D613. https://doi.org/10.1093/nar/gky1131

45. Scardoni G, Petterlini M, Laudanna C. Analyzing biological network parameters with CentiScaPe. Bioinformatics. 2009;25(21):2857-9. https://doi.org/10.1093/bioinformatics/btp517

46. Shannon P, Markiel A, Ozier O, Baliga NS, Wang JT, Ramage D, et al. Cytoscape: a software environment for integrated models of biomolecular interaction networks. Genome Res. 2003;13(11):2498-504. DOI: 10.1101/gr.1239303

47. Chen EY, Tan CM, Kou Y, Duan Q, Wang Z, Meirelles GV, et al. Enrichr: interactive and collaborative HTML5 gene list enrichment analysis tool. BMC Bioinformatics. 2013;14:128. https://doi.org/10.1186/1471-2105-14-128 
48. Kuleshov MV, Jones MR, Rouillard AD, Fernandez NF, Duan Q, Wang Z, et al. Enrichr: a comprehensive gene set enrichment analysis web server 2016 update. Nucleic Acids Res. 2016;44(W1):W90-7. https://doi.org/10.1093/nar/gkw377

49. Xie Z, Bailey A, Kuleshov MV, Clarke DJB, Evangelista JE, Jenkins SL, et al. Gene Set Knowledge Discovery with Enrichr. Curr Protoc. 2021;1(3):e90. https://doi.org/10.1002/cpz1.90

50. GTEx Consortium. The Genotype-Tissue Expression (GTEx) project. Nat Genet. 2013;45(6):580-5. https://doi.org/10.1038/ng.2653

51. Wishart DS, Feunang YD, Marcu A, Guo AC, Liang K, Vázquez-Fresno R, et al. HMDB 4.0: the human metabolome database for 2018. Nucleic Acids Res. 2018;46(D1):D608-D617. https://doi.org/10.1093/nar/gkx1089

52. Takematsu E, Spencer A, Auster J, Chen PC, Graham A, Martin P, et al. Genome wide analysis of gene expression changes in skin from patients with type 2 diabetes. PLoS One. 2020;15(2):e0225267. https://doi.org/10.1371/journal.pone.0225267

53. Palsgaard J, Brøns C, Friedrichsen M, Dominguez H, Jensen M, Storgaard H, et al. Gene expression in skeletal muscle biopsies from people with type 2 diabetes and relatives: differential regulation of insulin signaling pathways. PLoS One. 2009;4(8):e6575. https://doi.org/10.1371/journal.pone.0006575

54. Meugnier E, Faraj M, Rome S, Beauregard G, Michaut A, Pelloux V, et al. Acute hyperglycemia induces a global downregulation of gene expression in adipose tissue and skeletal muscle of healthy subjects. Diabetes. 2007;56(4):992-9. https://doi.org/10.2337/db06-1242

55. Yip L, Fuhlbrigge R, Alkhataybeh R, Fathman CG. Gene Expression Analysis of the Pre-Diabetic Pancreas to Identify Pathogenic Mechanisms and Biomarkers of Type 1 
Diabetes. Front $\quad$ Endocrinol (Lausanne). 2020;11:609271. https://doi.org/10.3389/fendo.2020.609271

56. Idicula-Thomas S, Gawde U, Bhaye S, Pokar K, Bader GD. Meta-analysis of gene expression profiles of lean and obese PCOS to identify differentially regulated pathways and risk of comorbidities. Comput Struct Biotechnol J. 2020;18:1735-1745. https://doi.org/10.1016/j.csbj.2020.06.023

57. Calimlioglu B, Karagoz K, Sevimoglu T, Kilic E, Gov E, Arga KY. Tissue-Specific Molecular Biomarker Signatures of Type 2 Diabetes: An Integrative Analysis of Transcriptomics and Protein-Protein Interaction Data. OMICS. 2015;19(9):563-73. https://doi.org/10.1089/omi.2015.0088

58. Solimena M, Schulte AM, Marselli L, Ehehalt F, Richter D, Kleeberg M, et al. Systems biology of the IMIDIA biobank from organ donors and pancreatectomised patients defines a novel transcriptomic signature of islets from individuals with type 2 diabetes. Diabetologia. 2018;61(3):641-657. https://doi.org/10.1007/s00125-017$\underline{4500-3}$

59. Sansbury FH, Flanagan SE, Houghton JA, Shuixian Shen FL, Al-Senani AM, Habeb AM, et al. SLC2A2 mutations can cause neonatal diabetes, suggesting GLUT2 may have a role in human insulin secretion. Diabetologia. 2012;55(9):2381-5. https://doi.org/10.1007/s00125-012-2595-0

60. Alhaidan Y, Christesen HT, Højlund K, Al Balwi MA, Brusgaard K. A novel gene in early childhood diabetes: EDEM2 silencing decreases SLC2A2 and PXD1 expression, leading to impaired insulin secretion. Mol Genet Genomics. 2020;295(5):1253-1262. https://doi.org/10.1007/s00438-020-01695-5

61. Abedini A, Schmidt AM. Mechanisms of islet amyloidosis toxicity in type 2 diabetes. FEBS Lett. 2013;587(8):1119-27. https://doi.org/10.1016/j.febslet.2013.01.017 
62. Sonne N, Karsdal MA, Henriksen K. Mono and dual agonists of the amylin, calcitonin, and CGRP receptors and their potential in metabolic diseases. Mol Metab. 2021;46:101109. https://doi.org/10.1016/j.molmet.2020.101109

63. Zhang XX, Qiao YC, Li W, Zou X, Chen YL, Shen J, et al. Human amylin induces CD4+Foxp3+ regulatory $\mathrm{T}$ cells in the protection from autoimmune diabetes. Immunol Res. 2018;66(1):179-186. https://doi.org/10.1007/s12026-017-8956-5

64. Corbi SCT, de Vasconcellos JF, Bastos AS, Bussaneli DG, da Silva BR, Santos RA, et al. Circulating lymphocytes and monocytes transcriptomic analysis of patients with type 2 diabetes mellitus, dyslipidemia and periodontitis. Sci Rep. 2020;10(1):8145. https://doi.org/10.1038/s41598-020-65042-9

65. Jacobi T, Massier L, Klöting N, Horn K, Schuch A, Ahnert P, et al. HLA Class II Allele Analyses Implicate Common Genetic Components in Type 1 and Non-InsulinTreated Type 2 Diabetes. J Clin Endocrinol Metab. 2020;105(3):dgaa027. https://doi.org/10.1210/clinem/dgaa027

66. Zhao LP, Alshiekh S, Zhao M, Carlsson A, Larsson HE, Forsander G, et al. NextGeneration Sequencing Reveals That HLA-DRB3, -DRB4, and -DRB5 May Be Associated With Islet Autoantibodies and Risk for Childhood Type 1 Diabetes. Diabetes. 2016;65(3):710-8. https://doi.org/10.2337/db15-1115

67. Yang S, Cao C, Xie Z, Zhou Z. Analysis of potential hub genes involved in the pathogenesis of Chinese type 1 diabetic patients. Ann Transl Med. 2020;8(6):295. DOI: $10.21037 / \mathrm{atm} .2020 .02 .171$

68. Kim J, Lee S. Effect of zinc supplementation on insulin resistance and metabolic risk factors in obese Korean women. Nutr Res Pract. 2012;6(3):221-5. https://doi.org/10.4162/nrp.2012.6.3.221 
69. Piuri G, Zocchi M, Della Porta M, Ficara V, Manoni M, Zuccotti GV, et al. Magnesium in Obesity, Metabolic Syndrome, and Type 2 Diabetes. Nutrients. 2021;13(2):320. https://doi.org/10.3390/nu13020320

70. Chen P, Bornhorst J, Diana Neely M, Avila DS. Mechanisms and Disease Pathogenesis Underlying Metal-Induced Oxidative Stress. Oxid Med Cell Longev. 2018;2018:7612172. https://doi.org/10.1155/2018/7612172

71. Wali JA, Masters SL, Thomas HE. Linking metabolic abnormalities to apoptotic pathways in Beta cells in type 2 diabetes. Cells. 2013;2(2):266-83. https://doi.org/10.3390/cells2020266

72. Jung DS, Lee SH, Kwak SJ, Li JJ, Kim DH, Nam BY, et al. Apoptosis occurs differentially according to glomerular size in diabetic kidney disease. Nephrol Dial Transplant. 2012;27(1):259-66. https://doi.org/10.1093/ndt/gfr301

73. Kageyama S, Yokoo H, Tomita K, Kageyama-Yahara N, Uchimido R, Matsuda N, et al. High glucose-induced apoptosis in human coronary artery endothelial cells involves up-regulation of death receptors. Cardiovasc Diabetol. 2011;10:73. https://doi.org/10.1186/1475-2840-10-73

74. Berbudi A, Rahmadika N, Tjahjadi AI, Ruslami R. Type 2 Diabetes and its Impact on the Immune System. Curr Diabetes Rev. 2020;16(5):442-449. DOI: $10.2174 / 1573399815666191024085838$

75. Selvin E, Juraschek SP. Diabetes Epidemiology in the COVID-19 Pandemic. Diabetes Care. 2020;43(8):1690-1694. https://doi.org/10.2337/dc20-1295

76. Apicella M, Campopiano MC, Mantuano M, Mazoni L, Coppelli A, Del Prato S. COVID-19 in people with diabetes: understanding the reasons for worse outcomes. Lancet Diabetes Endocrinol. 2020;8(9):782-792. https://doi.org/10.1016/S2213$\underline{8587(20) 30238-2}$ 


\section{TABLES}

Table 1: Number of differentially expressed genes in type 2 diabetes identified from different tissues of adult humans $(\mathrm{n}=\mathbf{2 7})$

\begin{tabular}{lllll}
\hline Dataset & $\begin{array}{l}\text { Number of DEGs } \\
(\mathbf{n}=\mathbf{6 2 8 4})\end{array}$ & $\begin{array}{l}\text { Upregulated }^{\mathbf{b}} \\
(\mathbf{n = 1 6 9 2})\end{array}$ & $\begin{array}{l}\text { Downregulated }^{\mathbf{c}} \\
(\mathbf{n = 4 5 9 2})\end{array}$ & Tissue \\
\hline GSE156993 & 0 & 0 & 0 & PBMC \\
GSE15932 & 309 & 79 & 230 & Peripheral blood \\
GSE21321 & 37 & 15 & 22 & Peripheral blood \\
GSE13015 & 3 & 0 & 3 & Whole blood \\
GSE13760 & 0 & 0 & 0 & Arterial tissue \\
GSE78721 & 1 & 0 & 1 & Adipocytes \\
GSE71416 & 13 & 0 & 13 & Omental adipose tissue \\
GSE54350 & 2 & 2 & 0 & Visceral adipose tissue \\
GSE29231 & 1655 & 1051 & 604 & Visceral adipose tissue \\
GSE16415 & 0 & 0 & 0 & Visceral adipose tissue \\
GSE29226 & 967 & 159 & 808 & Subcutaneous adipose tissue \\
GSE27949 & 0 & 0 & 0 & Subcutaneous adipose tissue \\
GSE76895 & 101 & 31 & 70 & Pancreatic islets \\
GSE76894 & 478 & 2 & 476 & Pancreatic islets \\
GSE38642 & 0 & 0 & 0 & Pancreatic islets \\
GSE25724 & 2164 & 76 & 2088 & Pancreatic islets \\
GSE20966 & 56 & 26 & 30 & Beta cells from pancreatic tissue \\
GSE64998 & 0 & 0 & 0 & Liver \\
GSE23343 & 0 & 0 & 0 & Liver \\
GSE15653 & 0 & 0 & 0 & Liver \\
GSE73034 & 0 & 0 & 0 & Skeletal muscle \\
GSE55650 & 30 & 9 & 21 & Skeletal muscle \\
GSE29221 & 185 & 26 & 159 & Skeletal muscle \\
GSE25462 & 8 & 6 & 2 & Skeletal muscle \\
\hline
\end{tabular}




\begin{tabular}{lllll}
\hline GSE19420 & 0 & 0 & 0 & Skeletal muscle \\
GSE22309 & 275 & 210 & 65 & Skeletal muscle \\
GSE21340 & 0 & 0 & 0 & Skeletal muscle \\
\hline
\end{tabular}

$\mathrm{a}=$ differentially expressed genes were defined as $\mathrm{BH}$-adjusted $\mathrm{p}$-value $<0.05 \& \log _{2} \mathrm{FC}>1 \mid \log _{2} \mathrm{FC}<-0.5 ; \mathrm{b}=$ Upregulated genes were defined as $\mathrm{BH}$-adjusted $\mathrm{p}$-value $<0.05 \& \log _{2} \mathrm{FC}>1$; $\mathrm{c}=$ Downregulated genes were defined as $\mathrm{BH}$-adjusted p-value $<0.05 \& \log _{2} \mathrm{FC}<-0.5$.

DEGs $=$ differentially expressed genes; PBMC $=$ peripheral blood mononuclear cells.

Table 2: Highly perturbed genes $(n=79)$ associated with type 2 diabetes identified by meta-analysis of microarray $(\mathbf{n}=16)$.

Approach Highly perturbed genes

Randomeffects model

Votecounting approach

Combining approach

Compiled set POPDC3, TAP2
49 genes: XYLT1, ISLR, CRTAC1, 35 genes: XYLT1, ISLR, ERAP2, PCOLCE2, VNN2, U2AF2, NPTX2, MMP9, LOC100008589, DYRK3, LOC649456, BCL3, ZNF423, SOD3, CNTFR, ZNF75, RNF19B, TNFAIP6, TAPBP, PHACTR3, PHLDA1, ALDOB, PRIMA1, PVRL2, CNTNAP2, RASL11B, POMZP3, ELFN1, ESPNL, PI3, SCN1B, EGR2, MGRN1, SLC9A3R2, LOC650885, UGT2B7, C19orf33, HLA-DRB4, OR8B12, HLADRB5, IFNA7, LOC389286, FUT11, APOL4, LOC731682, KIAA1984,

27 genes: LOC644422, MCL1, CTSC, 2 genes: LOC644422, MCL1 DYRK2, MCOLN3, TMEM37, API5, ARG2, C14orf132, COG2, DHRS2, ENPP2, ENTPD3, HADH, KIAA1279, LARP4, MARK1, MTRR, NAALAD2, PAAF1, PPM1K, PPP1R1A, RPL14, SLC2A2, SNAP25, STMN2, NMNAT2

8 genes: PCOLCE2, ERAP2, EGR2, ZBTB16, SLC2A2, ARG2, ASCL2, IAPP

79 genes: XYLT1, ISLR, CRTAC1, ERAP2, PCOLCE2, VNN2, U2AF2, NPTX2, MMP9, LOC100008589, DYRK3, LOC649456, BCL3, ZNF423, SOD3, CNTFR, ZNF75, RNF19B, LOC649456, BCL3, ZNF423, TNFAIP6, TAPBP, PHACTR3, PHLDA1, SOD3, CNTFR, ZNF75, RNF19B,
Down-regulated genes
14 genes: LOC650885, UGT2B7, C19orf33, HLA-DRB4, OR8B12, HLADRB5, IFNA7, LOC389286, FUT11, APOL4, LOC731682, KIAA1984, POPDC3, TAP2

25 genes: CTSC, DYRK2, MCOLN3, TMEM37, API5, ARG2, C14orf132, COG2, DHRS2, ENPP2, ENTPD3, HADH, KIAA1279, LARP4, MARK1, MTRR, NAALAD2, PAAF1, PPM1K, PPP1R1A, RPL14, SLC2A2, SNAP25, STMN2, NMNAT2

4 genes: PCOLCE2, ERAP2, 4 genes: SLC2A2, ARG2, ASCL2, IAPP EGR2, ZBTB16

38 genes: XYLT1, ISLR, 41 genes: LOC650885, UGT2B7, CRTAC1, ERAP2, PCOLCE2, C19orf33, HLA-DRB4, OR8B12, HLAVNN2, U2AF2, NPTX2, MMP9, DRB5, IFNA7, LOC389286, FUT11, LOC100008589, DYRK3, APOL4, LOC731682, KIAA1984, 3, POPDC3, TAP2, CTSC, DYRK2, MCOLN3, TMEM37, API5, ARG2, 


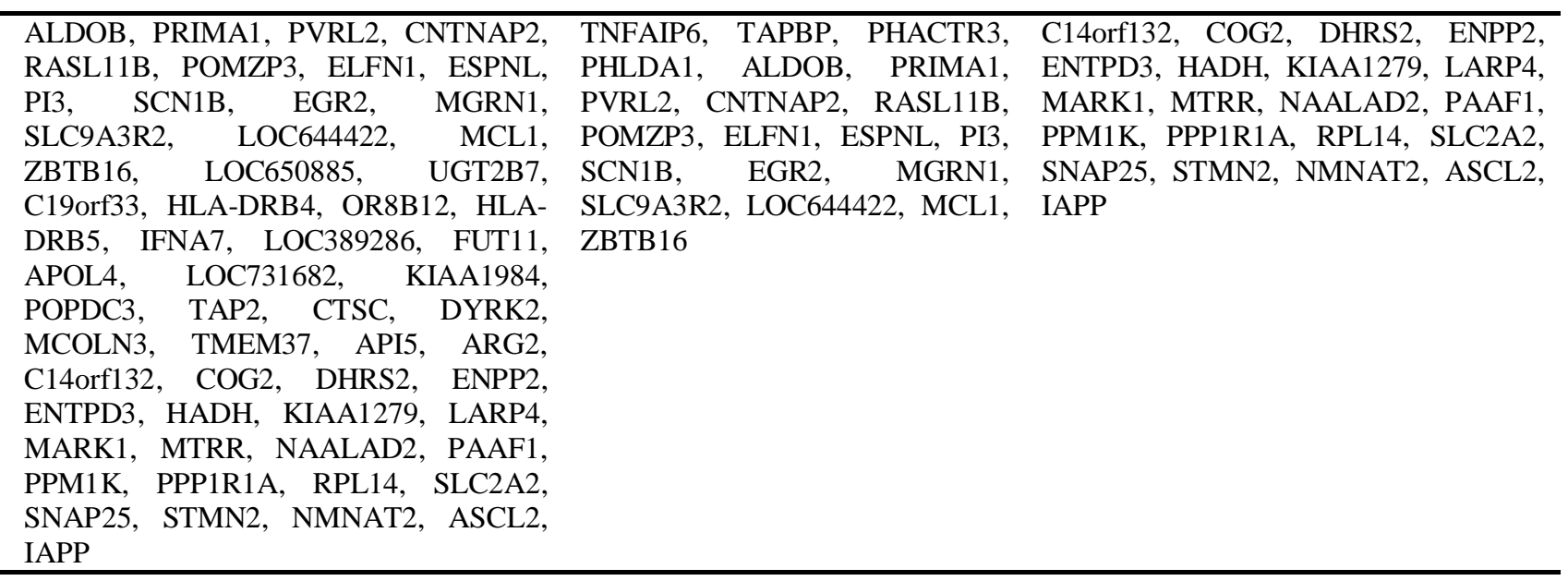

Table 3: Topological characteristics of the hub genes $(n=28)$ identified via network analyses

\begin{tabular}{|c|c|c|c|c|}
\hline \multirow[t]{2}{*}{ Gene } & Betweenness & Closeness & Degree & Regulation \\
\hline & mean $=115.5333333$ & mean $=0.004988249$ & mean $=12.68888889$ & \\
\hline PHLDA1 & 213.0074 & 0.005618 & 22 & Up-regulated \\
\hline CTSC & 149.7385 & 0.005495 & 18 & Down-regulated \\
\hline HADH & 208.3918 & 0.00578 & 18 & Down-regulated \\
\hline RPL14 & 139.3092 & 0.005464 & 17 & Down-regulated \\
\hline ZBTB16 & 127.1864 & 0.005405 & 14 & Up-regulated \\
\hline SOD3 & 198.8821 & 0.005714 & 21 & Up-regulated \\
\hline SNAP25 & 380.1873 & 0.005814 & 30 & Down-regulated \\
\hline SLC2A2 & 438.8331 & 0.005747 & 26 & Down-regulated \\
\hline ISLR & 465.6411 & 0.005952 & 27 & Up-regulated \\
\hline SCN1B & 175.7841 & 0.005376 & 14 & Up-regulated \\
\hline MMP9 & 196.9649 & 0.005682 & 22 & Up-regulated \\
\hline ENPP2 & 230.6537 & 0.005618 & 17 & Down-regulated \\
\hline TAP1* & 189.4171 & 0.005376 & 40 & - \\
\hline MCL1 & 320.3027 & 0.005917 & 27 & Up-regulated \\
\hline DPEP1* & 133.0483 & 0.005208 & 15 & - \\
\hline CNTNAP2 & 761.7546 & 0.006494 & 39 & Up-regulated \\
\hline STMN2 & 200.277 & 0.005618 & 18 & Down-regulated \\
\hline PPP1R1A & 219.8601 & 0.005587 & 18 & Down-regulated \\
\hline ZNF423 & 406.5439 & 0.006061 & 21 & Up-regulated \\
\hline CNTFR & 200.657 & 0.005319 & 16 & Up-regulated \\
\hline TNFAIP6 & 162.3969 & 0.005208 & 14 & Up-regulated \\
\hline PPP1R15A* & 119.5084 & 0.005155 & 13 & - \\
\hline XYLT1 & 194.4998 & 0.00565 & 18 & Up-regulated \\
\hline ZMIZ1* & 392.1699 & 0.005682 & 26 & - \\
\hline
\end{tabular}




\begin{tabular}{|c|c|c|c|c|}
\hline RASL11B & 168.9444 & 0.005376 & 13 & Up-regulated \\
\hline ARG1* & 124.961 & 0.005263 & 18 & - \\
\hline UGT2B7 & 247.0102 & 0.005682 & 19 & Down-regulated \\
\hline CD226* & 222.4953 & 0.005495 & 17 & - \\
\hline
\end{tabular}

*Genes included in the network as predicted by GENEMANIA

Table 4: Downstream analyses of highly perturbed genes $(n=79)$ associated with type 2 diabetes in different tissues of human adults: GO biological processes and KEGG pathways

\begin{tabular}{|c|c|c|c|c|c|c|c|}
\hline Term & Overlap & P-value & $\begin{array}{l}\text { Adjusted } \\
\text { P-value }\end{array}$ & $\begin{array}{l}\text { Odds } \\
\text { Ratio }\end{array}$ & $\begin{array}{l}\text { Combined } \\
\text { Score }\end{array}$ & Genes & $\begin{array}{l}\text { Regulation } \\
\text { in T2D }\end{array}$ \\
\hline $\begin{array}{l}\text { Ontologies: GO biological processes } \\
\text { Intrinsic apoptotic signalling pathway } \\
\text { in response to DNA damage } \\
(\mathrm{GO}: 0008630)\end{array}$ & $3 / 48$ & $9.03 \mathrm{E}-04$ & 0.230983 & 17.43509 & 122.2228 & $\begin{array}{l}\text { DYRK2; BCL3; } \\
\text { MCL1 }\end{array}$ & - \\
\hline $\begin{array}{l}\text { Intrinsic apoptotic signalling pathway } \\
\text { in response to DNA damage by p53 } \\
\text { class mediator (GO:0042771) }\end{array}$ & $2 / 20$ & 0.002795 & 0.230983 & 28.72006 & 168.8714 & DYRK2; BCL3 & - \\
\hline $\begin{array}{l}\text { Antigen processing and presentation of } \\
\text { peptide antigen via MHC class I } \\
\text { (GO:0002474) }\end{array}$ & $2 / 28$ & 0.005448 & 0.230983 & 19.87512 & 103.5986 & ERAP2; TAPBP & Up \\
\hline $\begin{array}{l}\text { Cellular response to oxidative stress } \\
\text { (GO:0034599) }\end{array}$ & $3 / 115$ & 0.010668 & 0.230983 & 6.981555 & 31.69995 & $\begin{array}{l}\text { MMP9; DHRS2; } \\
\text { SOD3 }\end{array}$ & - \\
\hline $\begin{array}{l}\text { Plasma membrane bounded cell } \\
\text { projection organization }(\mathrm{GO}: 0120036)\end{array}$ & $3 / 118$ & 0.011436 & 0.230983 & 6.798398 & 30.39569 & $\begin{array}{l}\text { CNTNAP2; } \\
\text { STMN2; NPTX2 }\end{array}$ & - \\
\hline $\begin{array}{l}\text { Intrinsic apoptotic signalling pathway } \\
\text { by p53 class mediator (GO:0072332) }\end{array}$ & $2 / 43$ & 0.012527 & 0.230983 & 12.59424 & 55.1606 & DYRK2; BCL3 & - \\
\hline $\begin{array}{l}\text { Myeloid cell differentiation } \\
\text { (GO:0030099) }\end{array}$ & $2 / 44$ & 0.013091 & 0.230983 & 12.29375 & 53.30386 & DYRK3; ZBTB16 & Up \\
\hline $\begin{array}{l}\text { Nicotinamide nucleotide metabolic } \\
\text { process (GO:0046496) }\end{array}$ & $2 / 45$ & 0.013665 & 0.230983 & 12.00725 & 51.54622 & $\begin{array}{l}\text { NMNAT2; } \\
\text { ALDOB }\end{array}$ & - \\
\hline $\begin{array}{l}\text { Regulation of intrinsic apoptotic } \\
\text { signalling pathway (GO:2001242) }\end{array}$ & $2 / 47$ & 0.014845 & 0.230983 & 11.47244 & 48.2997 & MMP9; MCL1 & Up \\
\hline $\begin{array}{l}\text { Myeloid leukocyte differentiation } \\
\text { (GO:0002573) } \\
\text { Pathways: KEGG }\end{array}$ & $2 / 50$ & 0.016695 & 0.230983 & 10.75379 & 44.01114 & MMP9; DHRS2 & - \\
\hline Epstein-Barr virus infection & $6 / 201$ & 0.000144 & 0.012503 & 8.31444 & 73.51986 & $\begin{array}{lr}\text { IFNA7; } & \text { HLA- } \\
\text { DRB5; } & \text { HLA- } \\
\text { DRB4; } & \text { ENTPD3; } \\
\text { TAP2; TAPBP }\end{array}$ & - \\
\hline
\end{tabular}




\begin{tabular}{|c|c|c|c|c|c|c|c|}
\hline Antigen processing and presentation & $4 / 77$ & 0.000245 & 0.012503 & 14.50082 & 120.5547 & HLA-DRB5; HLA- & - \\
\hline & & & & & & $\begin{array}{l}\text { DRB4; } \quad \text { TAP2; } \\
\text { TAPBP }\end{array}$ & \\
\hline Autoimmune thyroid disease & $3 / 53$ & 0.001205 & 0.040983 & 15.68763 & 105.436 & $\begin{array}{ll}\text { IFNA7; } & \text { HLA- } \\
\text { DRB5; } & \text { HLA- } \\
\text { DRB4 } & \end{array}$ & Down \\
\hline $\begin{array}{l}\text { Maturity onset diabetes of the young } \\
\text { (MODY) }\end{array}$ & $2 / 26$ & 0.004708 & 0.12006 & 21.53355 & 115.3862 & SLC2A2; IAPP & Down \\
\hline Asthma & $2 / 31$ & 0.006651 & 0.135681 & 17.81639 & 89.31323 & $\begin{array}{l}\text { HLA-DRB5; HLA- } \\
\text { DRB4 }\end{array}$ & Down \\
\hline Allograft rejection & $2 / 38$ & 0.009878 & 0.159725 & 14.34704 & 66.24726 & $\begin{array}{l}\text { HLA-DRB5; HLA- } \\
\text { DRB4 }\end{array}$ & Down \\
\hline Graft-versus-host disease & $2 / 41$ & 0.011434 & 0.159726 & 13.24142 & 59.20461 & $\begin{array}{l}\text { HLA-DRB5; HLA- } \\
\text { DRB4 }\end{array}$ & Down \\
\hline Type I diabetes mellitus (T1DM) & $2 / 43$ & 0.012527 & 0.159726 & 12.59423 & 55.1606 & $\begin{array}{l}\text { HLA-DRB5; HLA- } \\
\text { DRB4 }\end{array}$ & Down \\
\hline $\begin{array}{l}\text { Intestinal immune network for } \operatorname{IgA} \\
\text { production }\end{array}$ & $2 / 48$ & 0.015452 & 0.175118 & 11.22247 & 46.79817 & $\begin{array}{l}\text { HLA-DRB5; HLA- } \\
\text { DRB4 }\end{array}$ & Down \\
\hline Cell adhesion molecules (CAMs) & $3 / 145$ & 0.019771 & 0.181561 & 5.49824 & 21.5726 & $\begin{array}{ll}\text { CNTNAP2; } & \text { HLA- } \\
\text { DRB5; } & \text { HLA- } \\
\text { DRB4 } & \end{array}$ & - \\
\hline
\end{tabular}

$\mathrm{GO}=$ gene ontology; KEGG = Kyoto Encyclopedia of Genes and Genomes; T2D = type 2 diabetes

Table 5: Downstream analyses of highly perturbed genes $(n=79)$ associated with type 2 diabetes in different tissues of human adults: COVID-19 related gene sets and HMDB metabolites

\begin{tabular}{|c|c|c|c|c|c|c|c|}
\hline Term & Overlap & P-value & $\begin{array}{l}\text { Adjusted } \\
\text { P-value }\end{array}$ & $\begin{array}{l}\text { Odds } \\
\text { Ratio }\end{array}$ & $\begin{array}{l}\text { Combined } \\
\text { Score }\end{array}$ & Genes & $\begin{array}{l}\text { Regulation } \\
\text { in T2D }\end{array}$ \\
\hline \multicolumn{8}{|c|}{ Diseases: COVID-19 Related Gene Sets } \\
\hline $\begin{array}{l}\text { Up-regulated by SARS-CoV-2 } \\
\text { in pancreatic organoids from } \\
\text { GSE151803 }\end{array}$ & $9 / 500$ & 0.000155 & 0.01841 & 5.08787 & 44.64083 & $\begin{array}{l}\text { TMEM37; PPP1R1A; } \\
\text { VNN2; BCL3; TAP2; } \\
\text { ELFN1; } \\
\text { DHRS2; SCN1B }\end{array}$ & - \\
\hline $\begin{array}{l}\text { SARS Perturbation Down } \\
\text { Genes Mouse Lung from } \\
\text { GSE19137:GPL1261:2 }\end{array}$ & $5 / 246$ & 0.002908 & 0.08566 & 5.51755 & 32.22428 & $\begin{array}{l}\text { PCOLCE2; } \quad \text { RPL14; } \\
\text { HADH; CTSC; MCL1 }\end{array}$ & - \\
\hline $\begin{array}{l}\text { SARS Perturbation Up Genes } \\
\text { Mouse Lung from } \\
\text { GSE19137:GPL1261:3 }\end{array}$ & $6 / 366$ & 0.003262 & 0.08566 & 4.46598 & 25.56907 & $\begin{array}{l}\text { SLC9A3R2; } \\
\text { DLA- } \\
\text { URBAF2; } \\
\text { ZBTB16; RPL14; MCL1 }\end{array}$ & - \\
\hline $\begin{array}{l}\text { Healthy lung biopsy vs. } \\
\text { COVID-19 infected lung } \\
\text { series } 15 \text { from GSE147507 up } \\
\text { genes }\end{array}$ & $7 / 500$ & 0.003599 & 0.08566 & 3.8313 & 21.55896 & 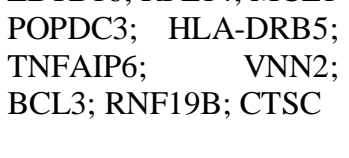 & - \\
\hline $\begin{array}{l}\text { Up-regulated by SARS-CoV-2 } \\
\text { in lung tissue from } \\
\text { GSE147507 }\end{array}$ & $7 / 500$ & 0.003599 & 0.08566 & 3.8313 & 21.55896 & $\begin{array}{lr}\text { POPDC3; } & \text { HLA-DRB5; } \\
\text { TNFAIP6; } & \text { VNN2; } \\
\text { BCL3; RNF19B; CTSC }\end{array}$ & - \\
\hline $\begin{array}{l}\text { SARS-CoV perturbation Up } \\
\text { Genes bronchial epithelial 2B4 } \\
\text { from GSE17400:GPL570:6 }\end{array}$ & $6 / 402$ & 0.005143 & 0.100484 & 4.05251 & 21.35735 & $\begin{array}{l}\text { ERAP2; VNN2; TAP2; } \\
\text { RNF19B; } \quad \text { PPM1K; } \\
\text { DHRS2 }\end{array}$ & - \\
\hline $\begin{array}{l}\text { SARS Perturbation Up Genes } \\
\text { Mouse Lung } \\
\text { GSE19137:GPL1261:5 }\end{array}$ & $5 / 291$ & 0.005911 & 0.100484 & 4.63877 & 23.80141 & $\begin{array}{l}\text { HLA-DRB5; } \quad \text { U2AF2; } \\
\text { ZBTB16; RPL14; MCL1 }\end{array}$ & - \\
\hline $\begin{array}{l}\text { Up-regulated by SARS-CoV-1 } \\
\text { in Calu-3 from GSE148729 }\end{array}$ & $6 / 498$ & 0.013921 & 0.16867 & 3.24574 & 13.87347 & $\begin{array}{l}\text { APOL4; EGR2; TAP2; } \\
\text { RNF19B; } \quad \text { PPM1K; } \\
\text { DHRS2 }\end{array}$ & - \\
\hline $\begin{array}{l}\text { Up-regulated by } \text { SARS-CoV-2 } \\
\text { in Calu-3 } 24 \mathrm{hr} \text { from } \\
\text { GSE148729 }\end{array}$ & $6 / 499$ & 0.014047 & 0.16867 & 3.23899 & 13.81541 & $\begin{array}{l}\text { APOL4; EGR2; ERAP2; } \\
\text { TAP2; } \quad \text { RNF19B; } \\
\text { PPM1K }\end{array}$ & - \\
\hline
\end{tabular}




\begin{tabular}{|c|c|c|c|c|c|c|c|}
\hline $\begin{array}{l}\text { Up-regulated by SARS-CoV-2 } \\
\text { in NHBE from GSE147507 }\end{array}$ & $6 / 500$ & 0.014174 & 0.16867 & 3.23227 & 13.75766 & $\begin{array}{l}\text { ENTPD3; BCL3; TAP2; } \\
\text { PI3; MMP9; CTSC }\end{array}$ & - \\
\hline \multicolumn{8}{|c|}{ Miscellaneous: HMDB Metabolites } \\
\hline Zinc (HMDB01303) & $4 / 82$ & 0.000312 & 0.025909 & 13.56786 & 109.52001 & $\begin{array}{l}\text { ZBTB16; } \\
\text { MMP9; SOD3 }\end{array}$ & Up \\
\hline Manganese (HMDB01333) & $4 / 193$ & 0.007193 & 0.127982 & 5.56811 & 27.4768 & $\begin{array}{l}\text { ARG2; DYRK2; } \\
\text { PPM1K; SOD3 }\end{array}$ & - \\
\hline Magnesium (HMDB00547) & $6 / 463$ & 0.009991 & 0.127982 & 3.50061 & 16.12387 & $\begin{array}{l}\text { DYRK3; } \quad \text { DYRK2; } \\
\text { ENTPD3; }\end{array}$ & - \\
\hline $\begin{array}{l}\text { C10H13N2O7P } \\
\text { (HMDB01570) }\end{array}$ & $1 / 11$ & 0.042612 & 0.127982 & 25.52692 & 80.55315 & ENTPD3 & Down \\
\hline
\end{tabular}

Table 6: Downstream analyses of highly perturbed genes $(n=79)$ associated with type 2 diabetes in different tissues of human adults: GTEx tissue sample gene expression profiles.

\begin{tabular}{|c|c|c|c|c|c|c|c|}
\hline Term & Overlap & P-value & $\begin{array}{l}\text { Adjusted } \\
\text { P-value }\end{array}$ & $\begin{array}{l}\text { Odds } \\
\text { Ratio }\end{array}$ & $\begin{array}{l}\text { Combined } \\
\text { Score }\end{array}$ & Genes & $\begin{array}{l}\text { Regulation } \\
\text { in T2D }\end{array}$ \\
\hline \multicolumn{8}{|c|}{ Cell Types: GTEx Tissue Sample Gene Expression Profiles Down } \\
\hline $\begin{array}{l}\text { GTEX-XUJ4- } \\
0726-S M-4 B O O P \\
\text { thyroid female 60- } \\
69 \text { years }\end{array}$ & $4 / 79$ & 0.00027 & 0.3129 & 14.1127 & 115.93606 & HLA-DRB5; STMN2; RNF19B; DHRS2 & - \\
\hline $\begin{array}{l}\text { GTEX-V955- } \\
\text { 0004-SM- } \\
\text { 3NMDH blood } \\
\text { male } 60-69 \text { years }\end{array}$ & $23 / 2789$ & 0.00034 & 0.3129 & 2.54729 & 20.28253 & $\begin{array}{l}\text { CNTFR; POPDC3; RASL11B; PCOLCE2; } \\
\text { ZBTB16; C14ORF132; } \quad \text { NMNAT2; } \\
\text { ASCL2; SOD3; POMZP3; SLC9A3R2; } \\
\text { APOL4; ISLR; PPP1R1A; CRTAC1; } \\
\text { PHACTR3; PI3; NPTX2; ZNF423; } \\
\text { PVRL2; SCN1B; PRIMA1; MARK1 }\end{array}$ & - \\
\hline $\begin{array}{l}\text { GTEX-XXEK- } \\
\text { 0004-SM- } \\
\text { 4BRWO blood } \\
\text { male 50-59 years }\end{array}$ & $24 / 3085$ & 0.00059 & 0.3129 & 2.40349 & 17.85933 & 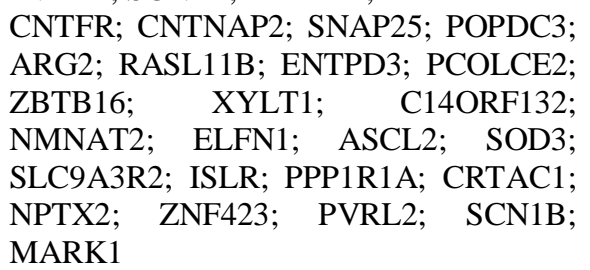 & - \\
\hline $\begin{array}{l}\text { GTEX-S7SE- } \\
\text { 0005-SM-2XCEA } \\
\text { blood male 50-59 } \\
\text { years }\end{array}$ & $23 / 2919$ & 0.00067 & 0.3129 & 2.41451 & 17.63845 & $\begin{array}{l}\text { POPDC3; ARG2; RASL11B; ENTPD3; } \\
\text { PCOLCE2; NMNAT2; LARP4; ELFN1; } \\
\text { SOD3; SLC9A3R2; TMEM37; ISLR; } \\
\text { ESPNL; KIAA1279; ENPP2; PHACTR3; } \\
\text { HADH; NPTX2; ZNF423; PVRL2; } \\
\text { SCN1B; PRIMA1; MARK1 }\end{array}$ & - \\
\hline $\begin{array}{l}\text { GTEX-XUYS- } \\
\text { 0005-SM-47JZ2 } \\
\text { blood male 50-59 } \\
\text { years }\end{array}$ & $24 / 3115$ & 0.00068 & 0.3129 & 2.37593 & 17.31639 & $\begin{array}{l}\text { CNTFR; SNAP25; POPDC3; DYRK3; } \\
\text { RASL11B; ENTPD3; PCOLCE2; } \\
\text { ZBTB16; NMNAT2; LARP4; SOD3; } \\
\text { SLC9A3R2; TMEM37; ISLR; KIAA1279; } \\
\text { PPP1R1A; CRTAC1; ENPP2; HADH; }\end{array}$ & - \\
\hline
\end{tabular}




\begin{tabular}{|c|c|c|c|c|c|c|c|}
\hline & & & & & & $\begin{array}{l}\text { NPTX2; ZNF423; } \quad \text { PHLDA1; } \quad \text { PVRL2; } \\
\text { MARK1 }\end{array}$ & \\
\hline $\begin{array}{l}\text { GTEX-XUJ4- } \\
\text { 0004-SM-4BOQE } \\
\text { blood female 60- } \\
69 \text { years }\end{array}$ & $25 / 3348$ & 0.00081 & 0.3129 & 2.31245 & 16.45932 & $\begin{array}{l}\text { SNAP25; PCOLCE2; STMN2; ELFN1; } \\
\text { ASCL2; SLC9A3R2; APOL4; ISLR; } \\
\text { CRTAC1; PHACTR3; PI3; ZNF423; } \\
\text { PHLDA1; SCN1B; PRIMA1; MARK1; } \\
\text { ARG2; ENTPD3; ZBTB16; C14ORF132; } \\
\text { NMNAT2; SOD3; PPP1R1A; ALDOB; } \\
\text { PVRL2 }\end{array}$ & - \\
\hline $\begin{array}{l}\text { GTEX-WL46- } \\
\text { 2826-SM-3LK81 } \\
\text { brain male 50-59 } \\
\text { years }\end{array}$ & $17 / 1966$ & 0.00149 & 0.33149 & 2.52838 & 16.44486 & $\begin{array}{l}\text { DYRK3; EGR2; MCOLN3; DYRK2; } \\
\text { TNFAIP6; PCOLCE2; ERAP2; MMP9; } \\
\text { ASCL2; SOD3; APOL4; ISLR; VNN2; } \\
\text { BCL3; PVRL2; CTSC; MCL1 }\end{array}$ & - \\
\hline $\begin{array}{l}\text { GTEX-TML8- } \\
\text { 0001-SM- } \\
\text { 3NMAF blood } \\
\text { female } \quad 40-49 \\
\text { years }\end{array}$ & $22 / 2914$ & 0.00161 & 0.33149 & 2.27268 & 14.60663 & $\begin{array}{l}\text { CNTFR; RASL11B; ENTPD3; PCOLCE2; } \\
\text { ZBTB16; STMN2; C14ORF132; } \\
\text { NMNAT2; ASCL2; SOD3; SLC9A3R2; } \\
\text { APOL4; ISLR; PPP1R1A; CRTAC1; } \\
\text { ALDOB; ZNF423; PHLDA1; PVRL2; } \\
\text { SCN1B; PRIMA1; MARK1 }\end{array}$ & - \\
\hline $\begin{array}{l}\text { GTEX-OIZF- } \\
\text { 0006-SM-2I5GQ } \\
\text { blood male 60-69 } \\
\text { years }\end{array}$ & $32 / 5000$ & 0.00172 & 0.33149 & 2.04927 & 13.03763 & $\begin{array}{l}\text { CNTFR; POPDC3; DYRK3; } \text { MTRR; } \\
\text { RASL11B; ELFN1; }\end{array}$ & - \\
\hline $\begin{array}{l}\text { GTEX-WFJO- } \\
\text { 0226-SM-3GIKW } \\
\text { thyroid male } 30- \\
39 \text { years }\end{array}$ & $5 / 222$ & 0.00186 & 0.33149 & 6.13526 & 38.55908 & $\begin{array}{l}\text { SNAP25; TNFAIP6; STMN2; ALDOB; } \\
\text { PI3 }\end{array}$ & - \\
\hline \multicolumn{8}{|c|}{ Cell Types: GTEx Tissue Sample Gene Expression Profiles Up } \\
\hline $\begin{array}{l}\text { GTEX-WHPG- } \\
\text { 0626-SM- } \\
\text { 3NMBD adipose } \\
\text { tissue male } 50-59 \\
\text { years }\end{array}$ & $12 / 778$ & 0.00005 & 0.147791 & 4.47878 & 44.22047 & $\begin{array}{l}\text { CNTFR; TMEM37; APOL4; DYRK3; } \\
\text { EGR2; HLA-DRB5; PCOLCE2; BCL3; } \\
\text { ENPP2; HADH; ZNF423; MCL1 }\end{array}$ & - \\
\hline $\begin{array}{l}\text { GTEX-XGQ4- } \\
\text { 1026-SM-4AT4L } \\
\text { adipose tissue } \\
\text { male 50-59 years }\end{array}$ & $9 / 598$ & 0.00057 & 0.448488 & 4.21994 & 31.48829 & $\begin{array}{l}\text { SLC9A3R2; CNTFR; APOL4; EGR2; } \\
\text { PPP1R1A; BCL3; HADH; ELFN1; MCL1 }\end{array}$ & - \\
\hline $\begin{array}{l}\text { GTEX-X88G- } \\
\text { 0226-SM-4GIE4 } \\
\text { adipose tissue } \\
\text { male } 30-39 \text { years }\end{array}$ & $11 / 872$ & 0.00061 & 0.448488 & 3.58099 & 26.50301 & $\begin{array}{llll}\text { TMEM37; } & \text { APOL4; } & \text { ISLR; } & \text { EGR2; } \\
\text { TNFAIP6; PCOLCE2; } & \text { ERAP2; } & \text { BCL3; } \\
\text { TAP2; CTSC; MCL1 } & & \end{array}$ & - \\
\hline $\begin{array}{l}\text { GTEX-WHPG- } \\
\text { 1426-SM- } \\
\text { 3NMBB lung } \\
\text { male 50-59 years }\end{array}$ & $13 / 1178$ & 0.00067 & 0.44848 & 3.17113 & 23.17132 & $\begin{array}{l}\text { HLA-DRB5; MTRR; TAP2; RNF19B; } \\
\text { MMP9; TAPBP; SLC9A3R2; APOL4; } \\
\text { VNN2; CRTAC1; BCL3; CTSC; MCL1 }\end{array}$ & - \\
\hline $\begin{array}{l}\text { GTEX-WH7G- } \\
1126-S M- \\
\text { 3NMBK adipose } \\
\text { tissue male } 40-49 \\
\text { years }\end{array}$ & $10 / 758$ & 0.00078 & 0.448488 & 3.71483 & 26.5752 & $\begin{array}{l}\text { CNTFR; APOL4; DYRK3; TNFAIP6; } \\
\text { PCOLCE2; PPP1R1A; BCL3; HADH; } \\
\text { ELFN1; MCL1 }\end{array}$ & - \\
\hline $\begin{array}{l}\text { GTEX-P4PP- } \\
\text { 3026-SM-3P610 }\end{array}$ & $7 / 434$ & 0.00163 & 0.71722 & 4.43852 & 28.4846 & $\begin{array}{l}\text { SLC9A3R2; CNTFR; APOL4; EGR2; } \\
\text { RASL11B; PCOLCE2; ZNF423 }\end{array}$ & - \\
\hline $\begin{array}{ll}\text { blood } & \text { vessel } \\
\text { female } & 30-39\end{array}$ & & & & & & & \\
\hline
\end{tabular}




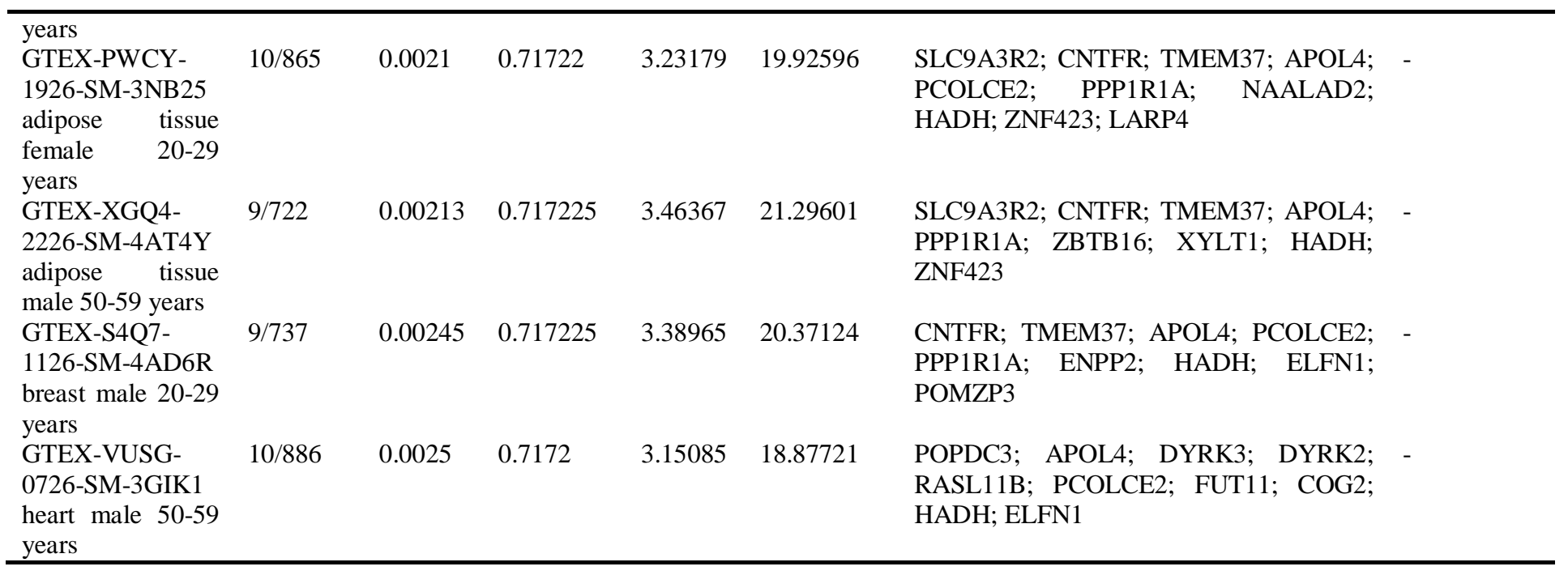

Table 7: Downstream analyses of hub genes $(n=28)$ associated with type 2 diabetes in different tissues of human adults: GO biological processes and KEGG pathways

\begin{tabular}{|c|c|c|c|c|c|c|c|}
\hline Term & Overlap & P-value & $\begin{array}{l}\text { Adjusted } \\
\text { P-value }\end{array}$ & $\begin{array}{l}\text { Odds } \\
\text { Ratio }\end{array}$ & $\begin{array}{l}\text { Combined } \\
\text { Score }\end{array}$ & Genes & $\begin{array}{l}\text { Regulation } \\
\text { in T2D }\end{array}$ \\
\hline \multicolumn{8}{|l|}{ Ontologies: GO biological processes } \\
\hline $\begin{array}{ll}\text { Neutrophil } & \text { degranulation } \\
\text { (GO:0043312) } & \end{array}$ & $5 / 479$ & 0.000481 & 0.061879 & 8.94239 & 68.31934 & $\begin{array}{l}\text { SNAP25; } \\
\text { TNFAIP6; ARG1; } \\
\text { MMP9; CTSC }\end{array}$ & - \\
\hline $\begin{array}{l}\text { Neutrophil activation involved in } \\
\text { immune response (GO:0002283) }\end{array}$ & $5 / 483$ & 0.000499 & 0.061878 & 8.86574 & 67.39777 & $\begin{array}{l}\text { SNAP25; } \\
\text { TNFAIP6; ARG1; } \\
\text { MMP9; CTSC }\end{array}$ & - \\
\hline $\begin{array}{l}\text { Neutrophil mediated immunity } \\
(\text { GO:0002446) }\end{array}$ & $5 / 487$ & 0.000518 & 0.061878 & 8.79036 & 66.49468 & $\begin{array}{l}\text { SNAP25; } \\
\text { TNFAIP6; ARG1; } \\
\text { MMP9; CTSC }\end{array}$ & - \\
\hline $\begin{array}{l}\text { Regulation of intrinsic apoptotic } \\
\text { signalling pathway (GO:2001242) }\end{array}$ & $2 / 47$ & 0.001965 & 0.081572 & 34.06324 & 212.28967 & MMP9; MCL1 & Up \\
\hline 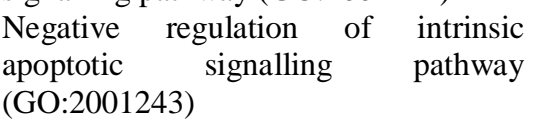 & $2 / 62$ & 0.003393 & 0.081572 & 25.5282 & 145.15226 & MMP9; MCL1 & Up \\
\hline $\begin{array}{l}\text { Positive regulation of cell projection } \\
\text { organization (GO:0031346) }\end{array}$ & $2 / 63$ & 0.003501 & 0.081572 & 25.10844 & 141.97721 & STMN2; SCN1B & - \\
\hline $\begin{array}{l}\text { Cellular response to reactive oxygen } \\
\text { species (GO:0034614) }\end{array}$ & $2 / 65$ & 0.003722 & 0.081572 & 24.30891 & 135.96666 & DPEP1; MMP9 & - \\
\hline $\begin{array}{l}\text { Negative regulation of apoptotic } \\
\text { signalling pathway (GO:2001234) }\end{array}$ & $2 / 65$ & 0.003722 & 0.081572 & 24.30891 & 135.96666 & MMP9; MCL1 & Up \\
\hline $\begin{array}{l}\text { Negative regulation of cysteine-type } \\
\text { endopeptidase activity involved in } \\
\text { apoptotic process (GO:0043154) }\end{array}$ & $2 / 68$ & 0.004066 & 0.081572 & 23.20046 & 127.71724 & DPEP1; MMP9 & - \\
\hline $\begin{array}{l}\text { Regulation of peptide hormone } \\
\text { secretion (GO:0090276) }\end{array}$ & $2 / 73$ & 0.004671 & 0.081572 & 21.56121 & 115.70462 & SNAP25; SLC2A2 & Down \\
\hline \multicolumn{8}{|l|}{ Pathways: KEGG } \\
\hline Insulin secretion & $2 / 86$ & 0.006424 & 0.166054 & 18.21245 & 91.9304 & SNAP25; SLC2A2 & Down \\
\hline Apoptosis & $2 / 143$ & 0.016992 & 0.166054 & 10.81887 & 44.08705 & CTSC; MCL1 & - \\
\hline
\end{tabular}




\begin{tabular}{|c|c|c|c|c|c|c|c|}
\hline $\begin{array}{lll}\text { Adrenergic } & \text { signalling } & \text { in } \\
\text { cardiomyocytes } & & \end{array}$ & $2 / 145$ & 0.017442 & 0.166054 & 10.66648 & 43.18703 & PPP1R1A; SCN1B & - \\
\hline Cell adhesion molecules (CAMs) & $2 / 145$ & 0.017442 & 0.166054 & 10.66648 & 43.18703 & CNTNAP2; CD226 & - \\
\hline JAK-STAT signalling pathway & $2 / 162$ & 0.021472 & 0.166054 & 9.525 & 36.58529 & CNTFR; MCL1 & $\mathrm{Up}$ \\
\hline $\begin{array}{l}\text { Transcriptional mis-regulation in } \\
\text { cancer }\end{array}$ & $2 / 186$ & 0.027752 & 0.166054 & 8.27257 & 29.65238 & ZВTB16; MMP9 & $\mathrm{Up}$ \\
\hline Arginine biosynthesis & $1 / 21$ & 0.029006 & 0.166054 & 36.94814 & 130.80559 & ARG1 & - \\
\hline $\begin{array}{l}\text { Maturity onset diabetes of the young } \\
\text { (MODY) }\end{array}$ & $1 / 26$ & 0.035792 & 0.166054 & 29.55111 & 98.40622 & SLC2A2 & Down \\
\hline Ascorbate and aldarate metabolism & $1 / 27$ & 0.037143 & 0.166054 & 28.4131 & 93.5634 & UGT2B7 & Down \\
\hline Fatty acid elongation & $1 / 27$ & 0.037143 & 0.166054 & 28.4131 & 93.5634 & HADH & Down \\
\hline
\end{tabular}

$\mathrm{GO}=$ gene ontology; KEGG = Kyoto Encyclopedia of Genes and Genomes; T2D = type 2 diabetes

Table 8: Downstream analyses of hub genes $(n=28)$ associated with type 2 diabetes in different tissues of human adults: COVID-19 related gene sets and HMDB metabolites

\begin{tabular}{|c|c|c|c|c|c|c|c|}
\hline Term & Overlap & P-value & $\begin{array}{l}\text { Adjusted } \\
\text { P-value }\end{array}$ & $\begin{array}{l}\text { Odds } \\
\text { Ratio }\end{array}$ & $\begin{array}{l}\text { Combined } \\
\text { Score }\end{array}$ & Genes & $\begin{array}{l}\text { Regulation } \\
\text { in T2D }\end{array}$ \\
\hline \multicolumn{8}{|c|}{ Diseases: COVID-19 Related Gene Sets } \\
\hline $\begin{array}{llr}\text { SARS } & \text { Perturbation Down } \\
\text { Genes } & \text { Mouse Lung from }\end{array}$ & $5 / 246$ & 0.000021 & 0.002066 & 17.79812 & 191.63596 & $\begin{array}{l}\text { RPL14; DPEP1; HADH; } \\
\text { CTSC; MCL1 }\end{array}$ & - \\
\hline GSE19137:GPL1261:2 & & & & & & & \\
\hline $\begin{array}{l}\text { Up-regulated by SARS-CoV-2 } \\
\text { in NHBE from GSE147507 }\end{array}$ & $4 / 500$ & 0.004909 & 0.106835 & 6.54435 & 34.79441 & $\begin{array}{l}\text { PPP1R15A; } \\
\text { MMP9; CTSC }\end{array}$ & - \\
\hline $\begin{array}{l}\text { Up-regulated by SARS-CoV-2 } \\
\text { in pancreatic organoids from } \\
\text { GSE151803 }\end{array}$ & $4 / 500$ & 0.004909 & 0.106835 & 6.54435 & 34.79441 & $\begin{array}{l}\text { PPP1R1A; } \\
\text { MMP9; SCN1B }\end{array}$ & - \\
\hline $\begin{array}{lrr}\text { SARS } & \text { perturbation } & \text { Down } \\
\text { Genes } & \text { airway } & \text { epithelium } \\
\text { (HAE) } & & \text { from }\end{array}$ & $3 / 264$ & 0.005837 & 0.106835 & 9.06253 & 46.61365 & $\begin{array}{l}\text { RASL11B; } \quad \text { ENPP2; } \\
\text { MMP9 }\end{array}$ & - \\
\hline GSE47961:GPL6480:2 & & & & & & & \\
\hline $\begin{array}{l}\text { SARS perturbation Up Genes } \\
\text { PBMCs GDS1028:GPL201 }\end{array}$ & $3 / 280$ & 0.006865 & 0.106835 & 8.53213 & 42.50101 & $\begin{array}{l}\text { PPP1R15A; } \quad \text { ARG1; } \\
\text { MMP9 }\end{array}$ & - \\
\hline $\begin{array}{l}\text { SARS-CoV-2/Human } \\
\text { Interactome Gene Set from } \\
\text { Guzzi }\end{array}$ & $2 / 92$ & 0.007319 & 0.106835 & 16.99316 & 83.55855 & ISLR; MCL1 & Up \\
\hline $\begin{array}{l}\text { SARS Perturbation Up Genes } \\
\text { Mouse Lung } \\
\text { GSE19137:GPL1261:5 }\end{array}$ & $3 / 291$ & 0.007631 & 0.106835 & 8.20166 & 39.98742 & ZBTB16; RPL14; MCL1 & - \\
\hline $\begin{array}{lr}\text { SARS Perturbation Up Genes } \\
\text { Mouse Lung } & \text { from } \\
\text { GSE68820:GPL7202:4 } & \end{array}$ & $3 / 357$ & 0.013276 & 0.142647 & 6.65016 & 28.74044 & TNFAIP6; ARG1; TAP1 & - \\
\hline $\begin{array}{l}\text { SARS Perturbation Up Genes } \\
\text { Mouse Lung } \\
\text { GSE19137:GPL1261:3 }\end{array}$ & $3 / 366$ & 0.014189 & 0.142647 & 6.48231 & 27.58368 & ZBTB16; RPL14; MCL1 & - \\
\hline $\begin{array}{l}\text { Down-regulated by IAV- } \\
\text { infection in mouse spleen }\end{array}$ & $3 / 455$ & 0.025142 & 0.142647 & 5.1823 & 19.08734 & ISLR; ENPP2; SOD3 & - \\
\hline
\end{tabular}




\begin{tabular}{|c|c|c|c|c|c|c|c|c|}
\hline \multicolumn{9}{|c|}{ Miscellaneous: HMDB Metabolites } \\
\hline Zinc (HMDB01303) & $4 / 82$ & 4.99E-06 & 0.000264 & 42.50854 & 518.98916 & $\begin{array}{l}\text { ZBTB16; } \\
\text { SOD3; MMP9 }\end{array}$ & DPEP1; & - \\
\hline $\begin{array}{ll}\text { Ethyl } & \text { glucuronide } \\
\text { (HMDB10325) } & \end{array}$ & $1 / 13$ & 0.018053 & 0.035712 & 61.60493 & 247.30909 & UGT2B7 & & Down \\
\hline $\begin{array}{l}\text { 3-Acetoacetyl-CoA } \\
\text { (HMDB01484) }\end{array}$ & $1 / 13$ & 0.018053 & 0.035712 & 61.60493 & 247.30909 & $\mathrm{HADH}$ & & Down \\
\hline $\begin{array}{l}\text { (S)-Methylmalonate } \\
\text { semialdehyde (HMDB02217) }\end{array}$ & $1 / 14$ & 0.019428 & 0.035712 & 56.86324 & 224.09815 & HADH & & Down \\
\hline $\begin{array}{l}\text { C18H31NO14S } \\
\text { (HMDB00632) }\end{array}$ & $1 / 14$ & 0.019428 & 0.035712 & 56.86324 & 224.09815 & XYLT1 & & Up \\
\hline Ornithine (HMDB00214) & $1 / 15$ & 0.020802 & 0.035712 & 52.79894 & 204.47351 & ARG1 & & - \\
\hline $\begin{array}{l}\text { 17beta-Estradiol glucuronide } \\
\text { (HMDB10317) }\end{array}$ & $1 / 19$ & 0.026278 & 0.035712 & 41.05761 & 149.40806 & UGT2B7 & & Down \\
\hline $\begin{array}{l}\text { (3alpha,5beta,20S)-20- } \\
\text { Hydroxypregnan-3-yl beta-D- } \\
\text { glucopyranosiduronic acid } \\
\text { (HMDB10318) }\end{array}$ & $1 / 19$ & 0.026278 & 0.035712 & 41.05761 & 149.40806 & UGT2B7 & & Down \\
\hline $\begin{array}{l}\text { 3,17-Androstanediol } \\
\text { glucuronide (HMDB10321) }\end{array}$ & $1 / 19$ & 0.026278 & 0.035712 & 41.05761 & 149.40806 & UGT2B7 & & Down \\
\hline $\begin{array}{l}\text { 17alpha-Estradiol-3- } \\
\text { glucuronide (HMDB10322) }\end{array}$ & $1 / 19$ & 0.026278 & 0.035712 & 41.05761 & 149.40806 & UGT2B7 & & Down \\
\hline
\end{tabular}

Table 9: Downstream analyses of hub genes $(n=28)$ associated with type 2 diabetes in different tissues of human adults: GTEx tissue sample gene expression profiles.

\begin{tabular}{|c|c|c|c|c|c|c|c|}
\hline Term & Overlap & P-value & $\begin{array}{l}\text { Adjusted } \\
\text { P-value }\end{array}$ & $\begin{array}{l}\text { Odds } \\
\text { Ratio }\end{array}$ & $\begin{array}{l}\text { Combined } \\
\text { Score }\end{array}$ & Genes & $\begin{array}{l}\text { Regulation } \\
\text { in T2D }\end{array}$ \\
\hline \multicolumn{8}{|c|}{ Cell Types: GTEx Tissue Sample Gene Expression Profiles Down } \\
\hline $\begin{array}{l}\text { GTEX-OHPK-1726- } \\
\text { SM-48TC4 nerve } \\
\text { female 50-59 years }\end{array}$ & $4 / 178$ & 0.00010 & 0.140263 & 18.9636 & 173.71976 & $\begin{array}{l}\text { SNAP25; CNTNAP2; } \text { ARG1; } \\
\text { CD226 }\end{array}$ & - \\
\hline $\begin{array}{l}\text { GTEX-R55E-0011- } \\
\text { R11A-SM-2TC6I brain } \\
\text { male 20-29 years }\end{array}$ & $8 / 1275$ & 0.00026 & 0.140263 & 5.905288 & 48.68668 & $\begin{array}{l}\text { TNFAIP6; ZBTB16; RPL14; } \\
\text { TAP1; DPEP1; MMP9; CTSC; } \\
\text { MCL1 }\end{array}$ & - \\
\hline $\begin{array}{l}\text { GTEX-N7MS-0011- } \\
\text { R11A-SM-2HMJS } \\
\text { brain male 60-69 years }\end{array}$ & $10 / 2072$ & 0.00031 & 0.140263 & 4.82541 & 38.89372 & $\begin{array}{l}\text { ISLR; } \quad \text { TNFAIP6; ZBTB16; } \\
\text { XYLT1; TAP1; CD226; SOD3; } \\
\text { MMP9; CTSC; MCL1 }\end{array}$ & - \\
\hline $\begin{array}{l}\text { GTEX-PVOW-2726- } \\
\text { SM-48TCA pituitary } \\
\text { male 40-49 years }\end{array}$ & $5 / 447$ & 0.00035 & 0.140263 & 9.60554 & 76.42437 & $\begin{array}{l}\text { TNFAIP6; ARG1; } \text { ZBTB16; } \\
\text { XYLT1; MCL1 }\end{array}$ & - \\
\hline $\begin{array}{l}\text { GTEX-T6MN-0002- } \\
\text { SM-3NMAH blood } \\
\text { male 50-59 years }\end{array}$ & $12 / 2999$ & 0.00036 & 0.140263 & 4.26473 & 33.74814 & $\begin{array}{l}\text { CNTNAP2; CNTFR; ISLR; } \\
\text { RASL11B; PPP1R1A; ZBTB16; } \\
\text { STMN2; DPEP1; ZNF423; } \\
\text { PHLDA1; SOD3; SCN1B }\end{array}$ & - \\
\hline $\begin{array}{l}\text { GTEX-PSDG-1626- } \\
\text { SM-48TCQ breast male } \\
\text { 50-59 years }\end{array}$ & $5 / 487$ & 0.00051 & 0.165673 & 8.79036 & 66.49468 & $\begin{array}{ll}\text { SNAP25; } & \text { CNTNAP2; } \\
\text { RASL11B; STMN2; CD226 }\end{array}$ & - \\
\hline $\begin{array}{l}\text { GTEX-SNOS-0526- } \\
\text { SM-4DM54 bladder } \\
\text { male } 40-49 \text { years }\end{array}$ & $3 / 144$ & 0.00104 & 0.232779 & 16.87744 & 115.77124 & TNFAIP6; PPP1R1A; STMN2 & - \\
\hline $\begin{array}{l}\text { GTEX-R55E-2526- } \\
\text { SM-2TC6H brain male } \\
\text { 20-29 years }\end{array}$ & $5 / 570$ & 0.00105 & 0.232779 & 7.4671 & 51.1853 & $\begin{array}{l}\text { TNFAIP6; ZBTB16; } \\
\text { DPPEP1; CTSC }\end{array}$ & - \\
\hline $\begin{array}{l}\text { GTEX-TML8-0001- } \\
\text { SM-3NMAF blood } \\
\text { female 40-49 years }\end{array}$ & $11 / 2914$ & 0.00119 & 0.232779 & 3.80456 & 25.59278 & 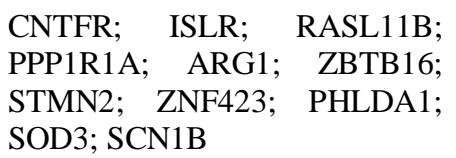 & - \\
\hline
\end{tabular}




\begin{tabular}{|c|c|c|c|c|c|c|c|}
\hline $\begin{array}{l}\text { GTEX-XYKS-0002- } \\
\text { SM-4BRWN blood } \\
\text { female 60-69 years }\end{array}$ & $11 / 2979$ & 0.001443 & 0.232779 & 3.70707 & 24.24791 & $\begin{array}{l}\text { SNAP25; CNTNAP2; CNTFR; } \\
\text { ISLR; RASL11B; PPP1R1A; } \\
\text { ZBTB16; STMN2; ZNF423; } \\
\text { SOD3; SCN1B }\end{array}$ & - \\
\hline \multicolumn{8}{|c|}{ Cell Types: GTEx Tissue Sample Gene Expression Profiles Up } \\
\hline $\begin{array}{l}\text { GTEX-XGQ4-2226- } \\
\text { SM-4AT4Y adipose } \\
\text { tissue male 50-59 years }\end{array}$ & $6 / 722$ & 0.000413 & 0.606044 & 7.33469 & 57.14262 & $\begin{array}{l}\text { CNTFR; PPP1R1A; ZBTB16; } \\
\text { XYLT1; HADH; ZNF423 }\end{array}$ & - \\
\hline $\begin{array}{l}\text { GTEX-XGQ4-1026- } \\
\text { SM-4AT4L adipose } \\
\text { tissue male 50-59 years }\end{array}$ & $5 / 598$ & 0.001305 & 0.606044 & 7.10426 & 47.18102 & $\begin{array}{l}\text { PPP1R15A; CNTFR; PPP1R1A; } \\
\text { HADH; MCL1 }\end{array}$ & - \\
\hline $\begin{array}{l}\text { GTEX-W5X1-0008- } \\
\text { SM-4LMKA skin } \\
\text { female 40-49 years }\end{array}$ & $6 / 955$ & 0.001779 & 0.606044 & 5.466902 & 34.61318 & $\begin{array}{l}\text { ISLR; RPL14; ENPP2; XYLT1; } \\
\text { DPEP1; CTSC }\end{array}$ & - \\
\hline $\begin{array}{l}\text { GTEX-QV44-0008- } \\
\text { SM-447AX skin male } \\
50-59 \text { years }\end{array}$ & $8 / 1765$ & 0.002254 & 0.606044 & 4.14684 & 25.2735 & $\begin{array}{l}\text { PPP1R15A; ISLR; RASL11B; } \\
\text { ENPP2; XYLT1; PHLDA1; } \\
\text { CTSC; MCL1 }\end{array}$ & - \\
\hline $\begin{array}{l}\text { GTEX-XBED-1326- } \\
\text { SM-4AT4F adipose } \\
\text { tissue male 60-69 years }\end{array}$ & $5 / 690$ & 0.002448 & 0.606044 & 6.120913 & 36.80156 & $\begin{array}{l}\text { PPP1R15A; CNTFR; ENPP2; } \\
\text { MMP9; MCL1 }\end{array}$ & - \\
\hline $\begin{array}{l}\text { GTEX-R55C-1626- } \\
\text { SM-48FEG adipose } \\
\text { tissue male } 40-49 \text { years }\end{array}$ & $5 / 720$ & 0.002943 & 0.606044 & 5.854971 & 34.12304 & $\begin{array}{l}\text { CNTFR; PPP1R1A; ZBTB16; } \\
\text { ENPP2; XYLT1 }\end{array}$ & - \\
\hline $\begin{array}{l}\text { GTEX-XUW1-0526- } \\
\text { SM-4BOP3 adipose } \\
\text { tissue female } 50-59 \\
\text { years }\end{array}$ & $5 / 735$ & 0.003217 & 0.606044 & 5.730196 & 32.88661 & $\begin{array}{l}\text { CNTFR; PPP1R1A; ZBTB16; } \\
\text { ENPP2; HADH }\end{array}$ & - \\
\hline $\begin{array}{l}\text { GTEX-R55C-0005- } \\
\text { SM-3GAE9 blood male } \\
\text { 40-49 years }\end{array}$ & $6 / 1090$ & 0.003461 & 0.606044 & 4.752096 & 26.92674 & $\begin{array}{l}\text { TNFAIP6; } \quad \text { ARG1; } \quad \text { CD226; } \\
\text { MMP9; CTSC; MCL1 }\end{array}$ & - \\
\hline $\begin{array}{l}\text { GTEX-WH7G-1126- } \\
\text { SM-3NMBK adipose } \\
\text { tissue male } 40-49 \text { years }\end{array}$ & $5 / 758$ & 0.003672 & 0.606044 & 5.54853 & 31.11036 & $\begin{array}{l}\text { CNTFR; TNFAIP6; PPP1R1A; } \\
\text { HADH; MCL1 }\end{array}$ & - \\
\hline $\begin{array}{l}\text { GTEX-OIZH-0005- } \\
\text { SM-2HMJN blood } \\
\text { male 50-59 years }\end{array}$ & $6 / 1105$ & 0.003703 & 0.606044 & 4.68351 & 26.221 & $\begin{array}{l}\text { TNFAIP6; } \quad \text { ARG1; } \\
\text { CD226; MMP9; MCL1 }\end{array}$ & - \\
\hline
\end{tabular}




\section{FIGURES}

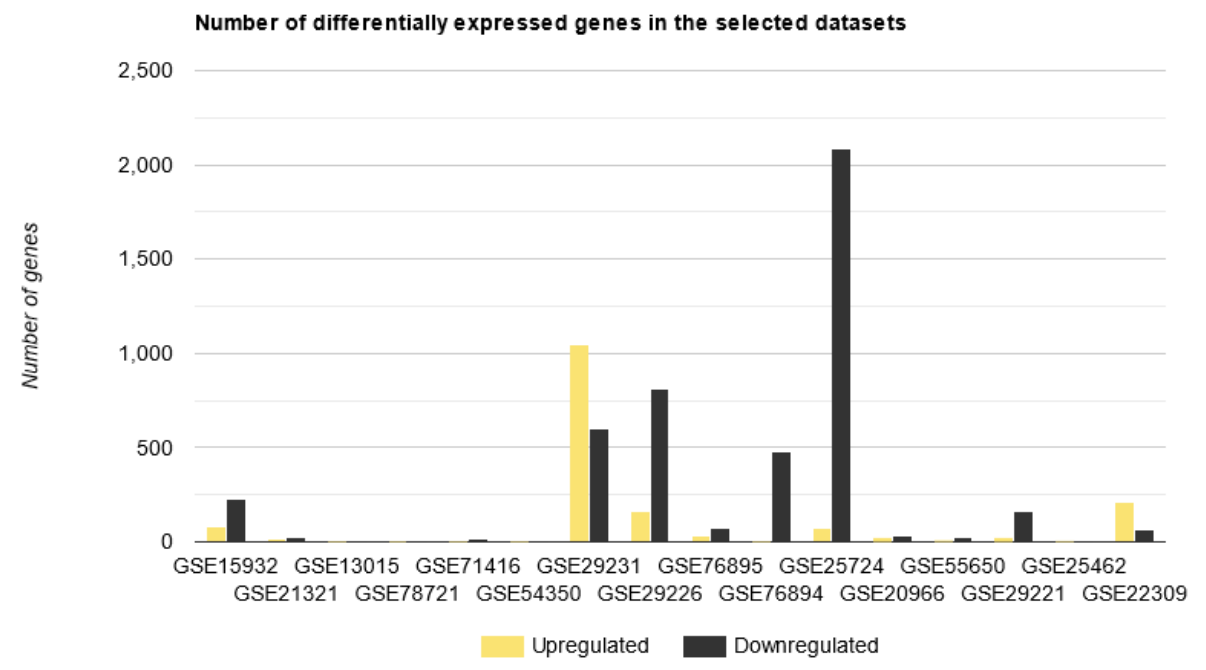

Figure 1: Stacked bar chart depicting the number of differentially expressed (up- and down-regulated) genes in the 16 datasets. 


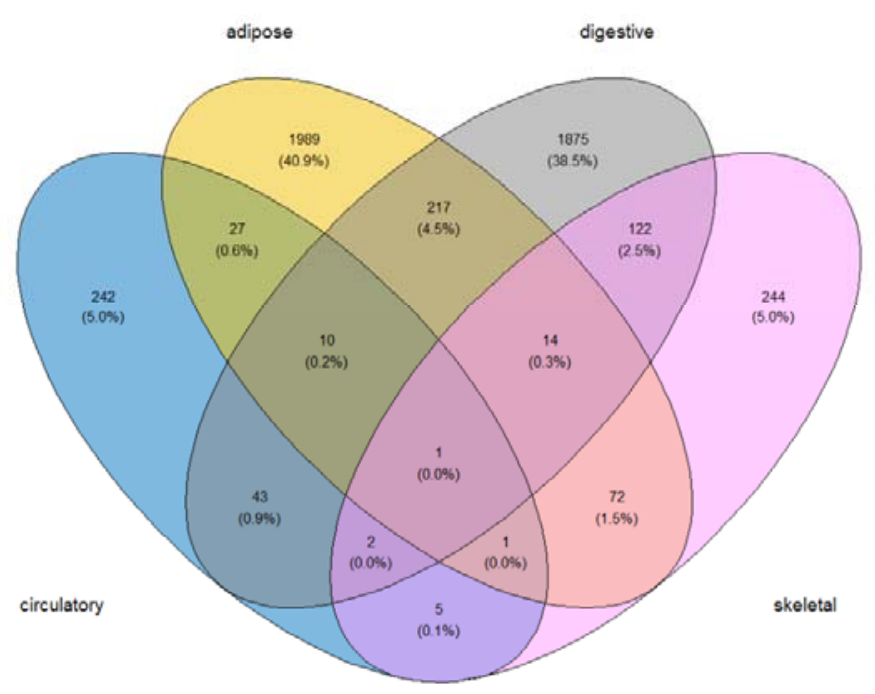

Figure 2: Venn diagram depicting the number of differentially expressed genes by the 4 tissue types. 


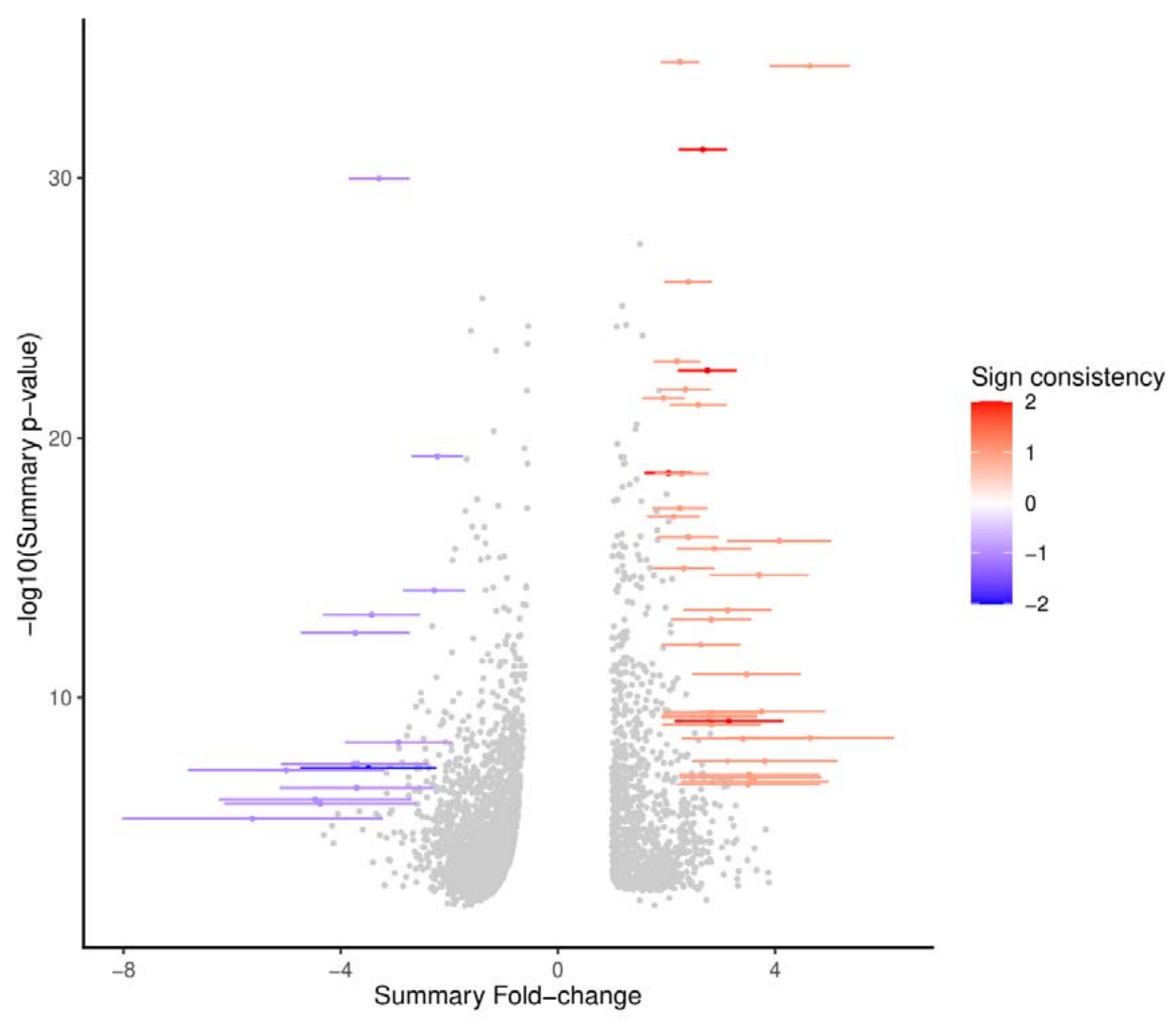

Figure 3: Highly perturbed genes $(n=49)$ identified by random effects model meta-analysis in 'MetaVolcanoR' package with 'metathr' set at 0.01 . Consistently upregulated genes appear in red and consistently downregulated genes appear in blue. 


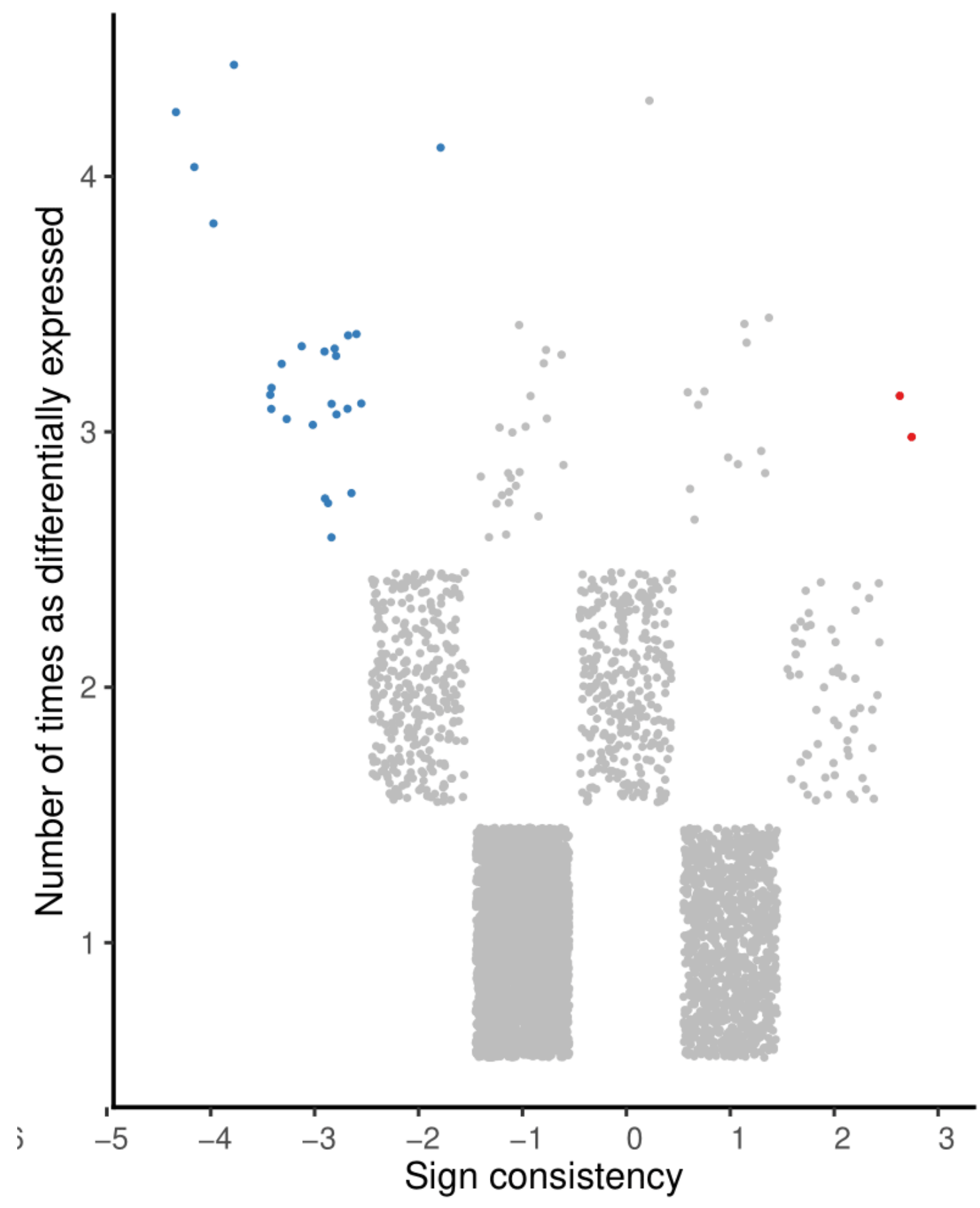

Figure 4: Highly perturbed genes $(n=27)$ identified by vote-counting approach meta-analysis in 'MetaVolcanoR' package with 'metathr' set at 0.01 . Consistently upregulated genes appear in red and consistently downregulated genes appear in blue. 


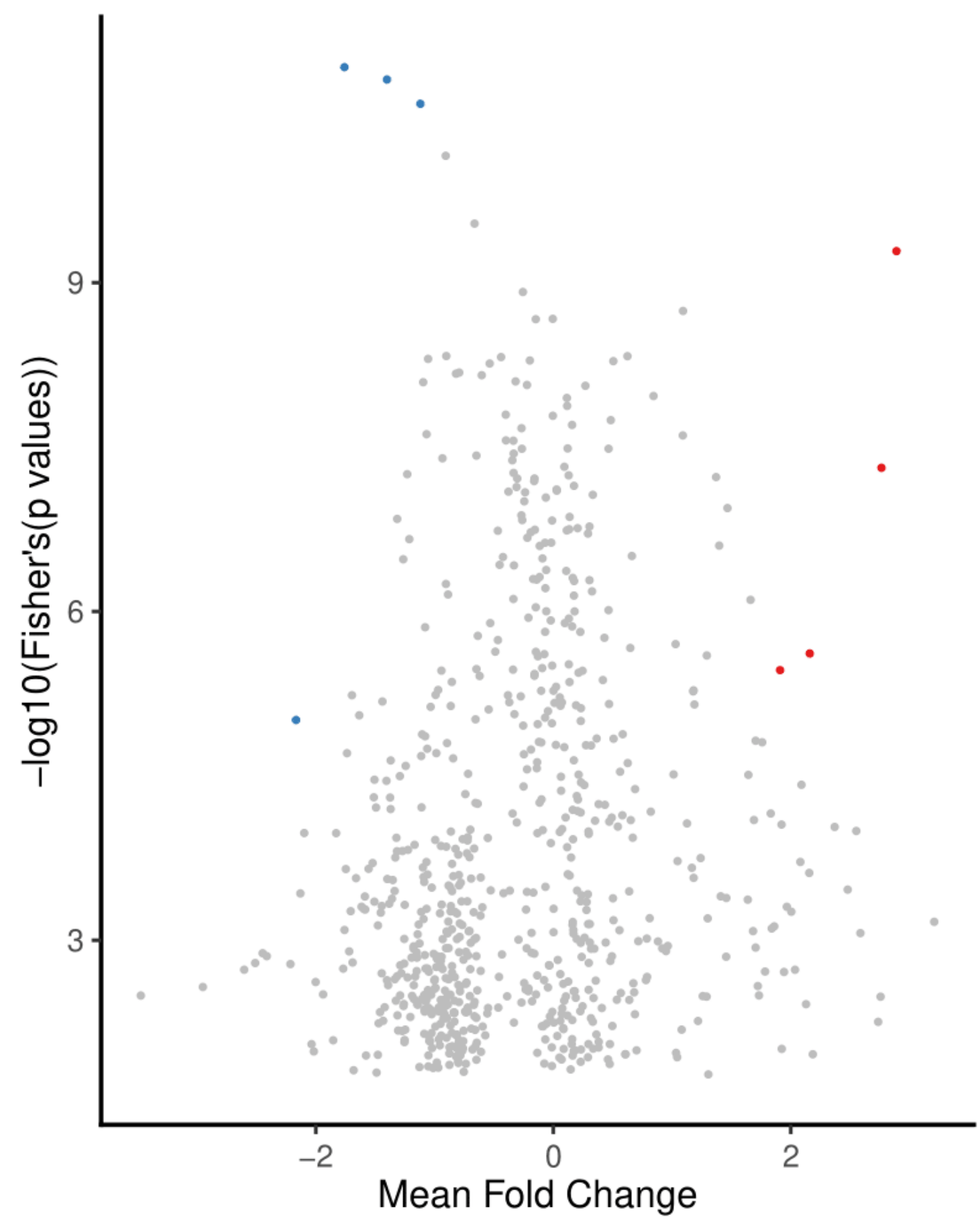

Figure 5: Highly perturbed genes $(n=8)$ identified by $p$-value combining approach meta-analysis in 'MetaVolcanoR' package with 'metathr' set at 0.01 . Consistently upregulated genes appear in red and consistently downregulated genes appear in blue. 

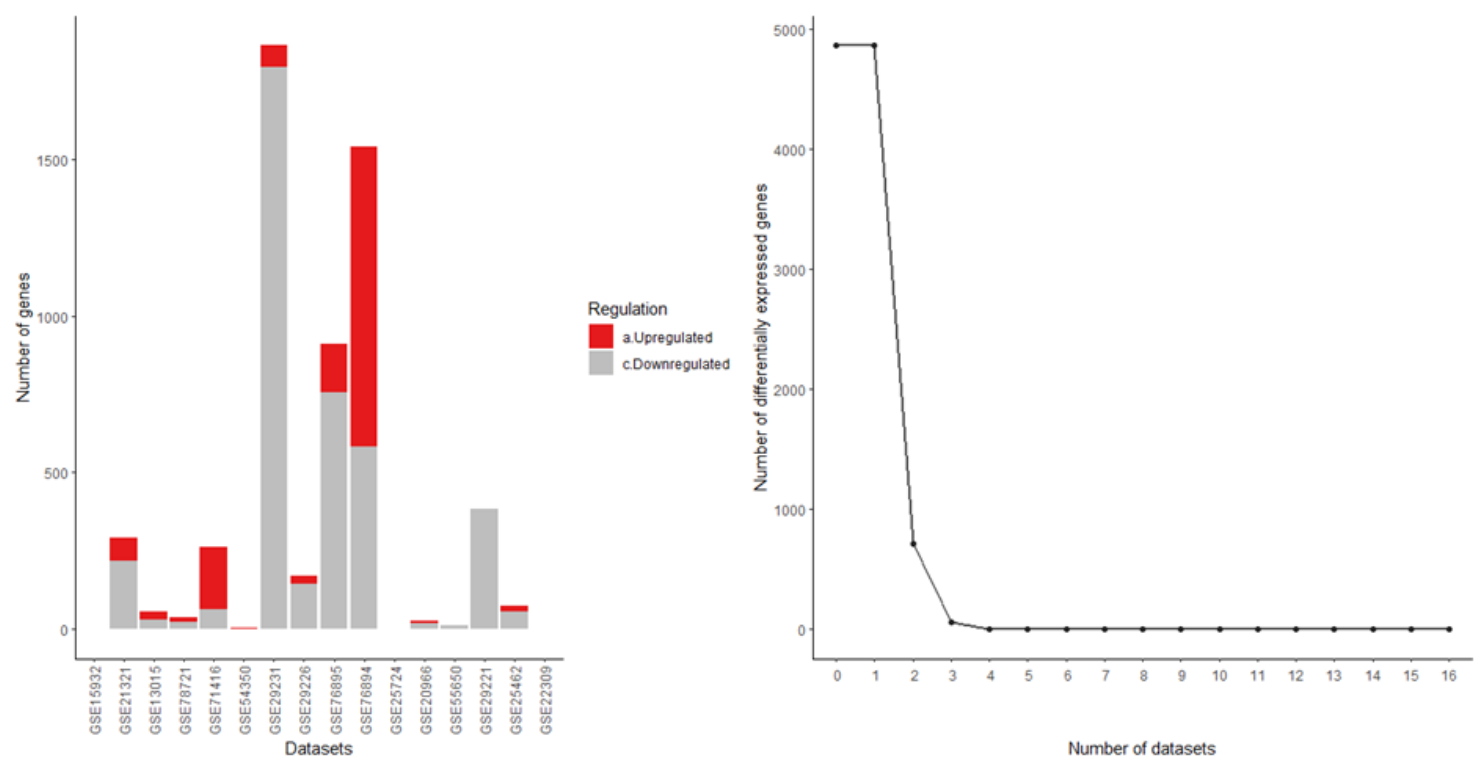

Figure 6: Inverse cumulative distribution of the consistently differentially expressed genes as per votecounting approach.

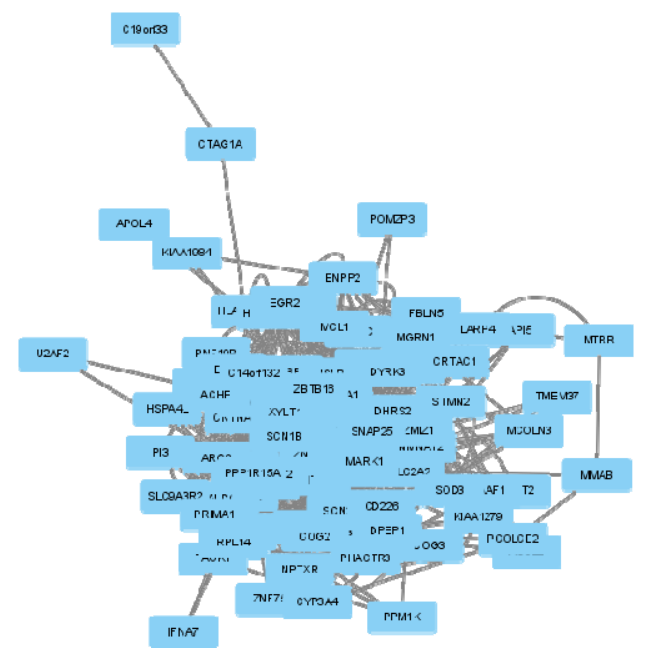

Figure 7: Gene-gene interactions network visualized in GENEMANIA 
bioRxiv preprint doi: https://doi.org/10.1101/2022.02.07.479483; this version posted February 10, 2022. The copyright holder for this preprint (which was not certified by peer review) is the author/funder. All rights reserved. No reuse allowed without permission.

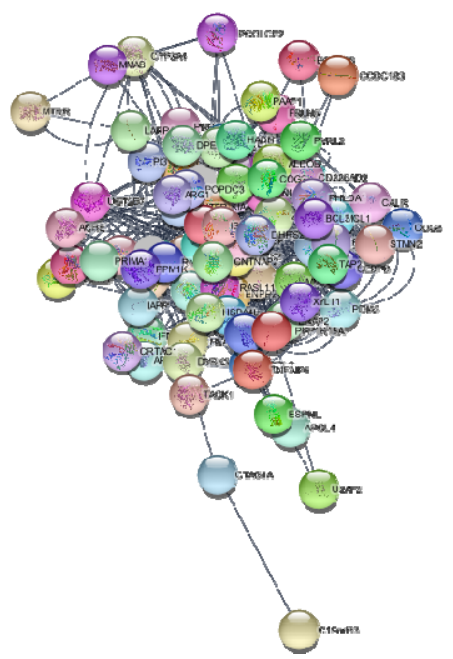

Figure 8: Protein-protein interactions network visualized in STRING 


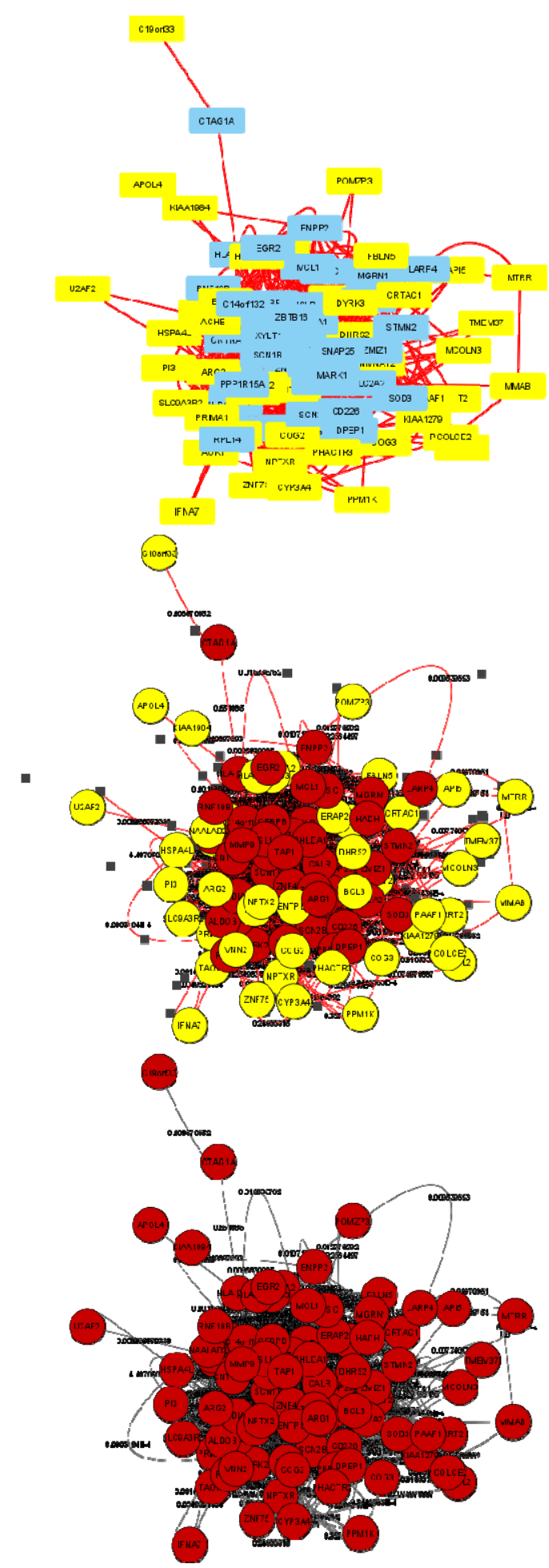

Figure 9: Three different presentations of the protein-protein interactions network in Centiscape. 
bioRxiv preprint doi: https://doi.org/10.1101/2022.02.07.479483; this version posted February 10, 2022. The copyright holder for this preprint (which was not certified by peer review) is the author/funder. All rights reserved. No reuse allowed without permission.

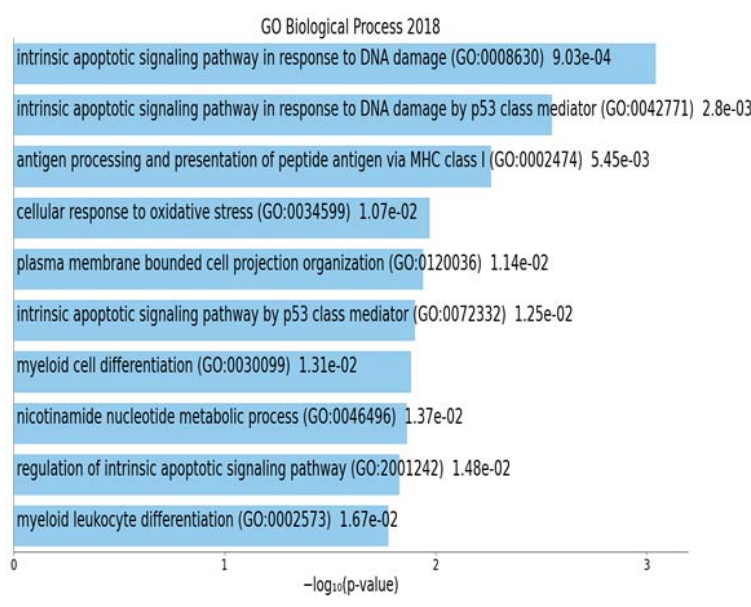

(a)

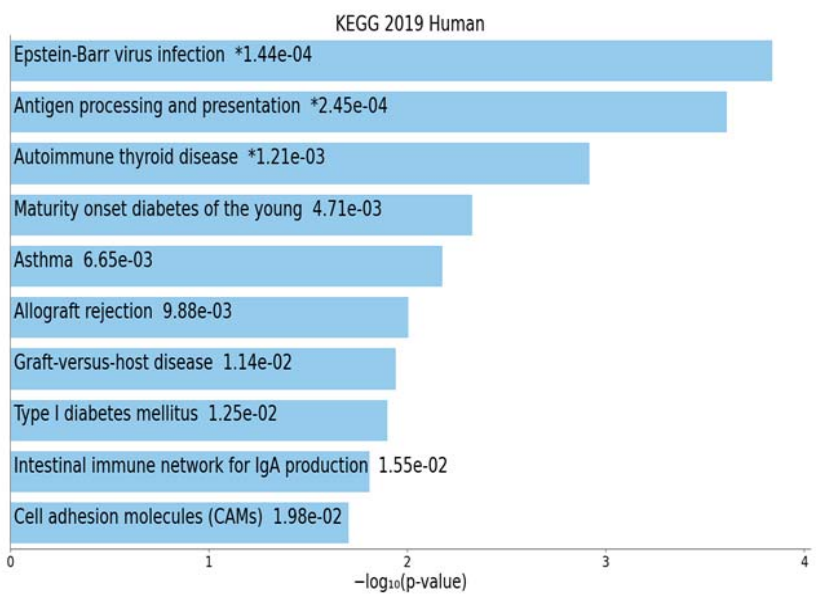

(b)

Figure 10: Downstream analyses of highly perturbed genes $(n=79)$ associated with type 2 diabetes in different tissues of human adults: (a) GO biological processes (b) KEGG pathways.

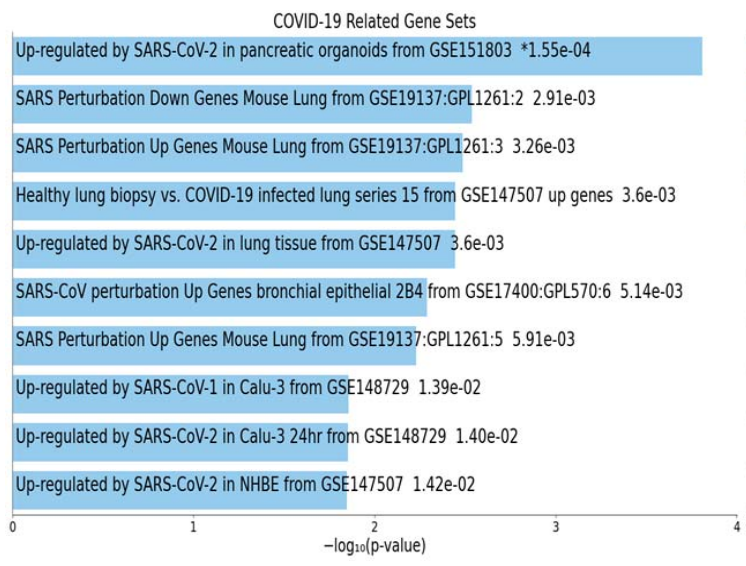

(a)

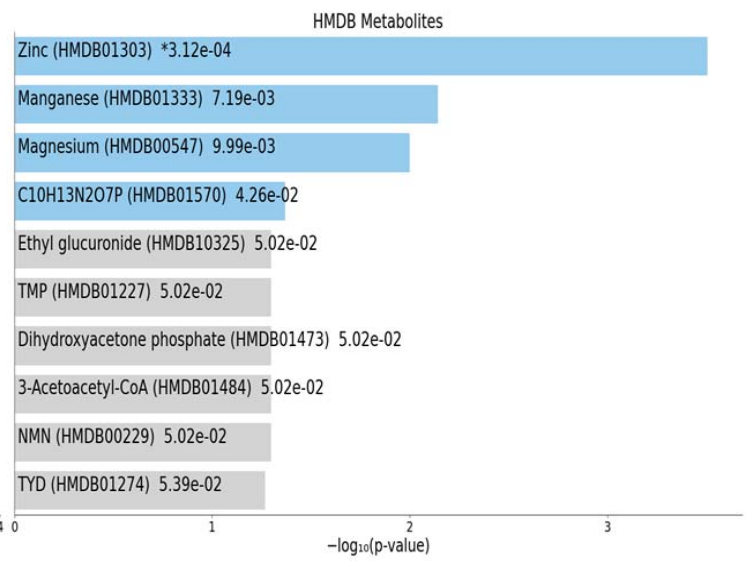

(b)

Figure 11: Downstream analyses of highly perturbed genes $(n=79)$ associated with type 2 diabetes in different tissues of human adults: (a) COVID-19 related gene sets (b) HMDB metabolites. 


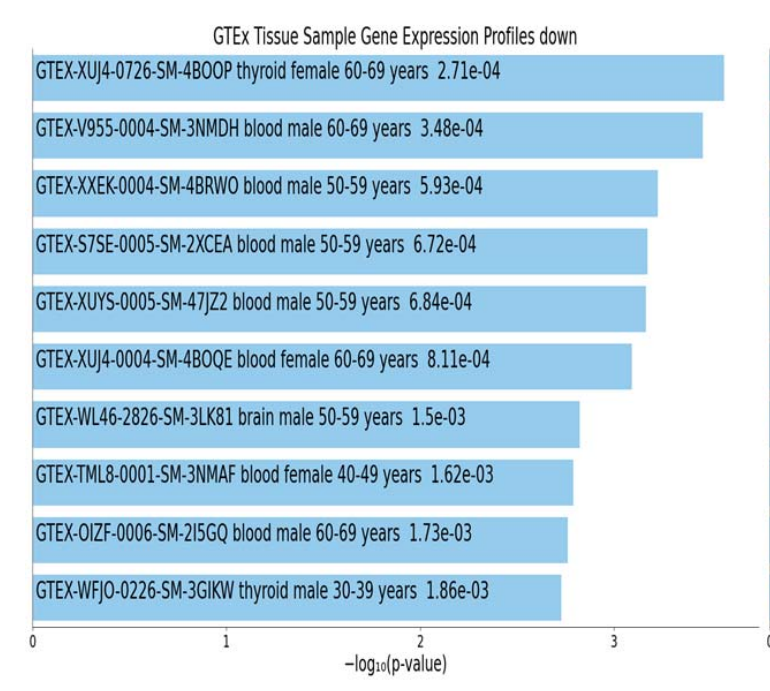

(a)

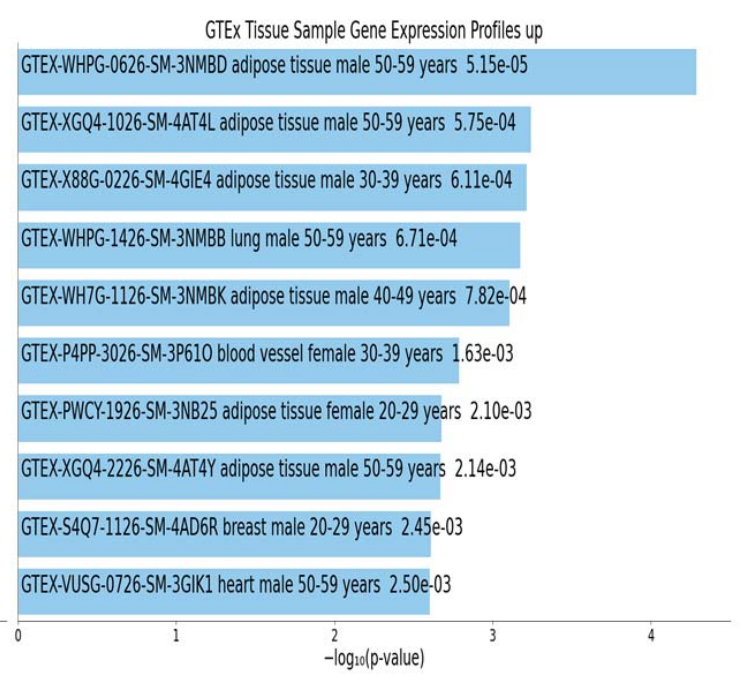

(b)

Figure 12: Downstream analyses of highly perturbed genes $(n=79)$ associated with type 2 diabetes in different tissues of human adults: (a) GTEx tissue sample gene expression profiles down. (b) GTEx tissue sample gene expression profiles up.

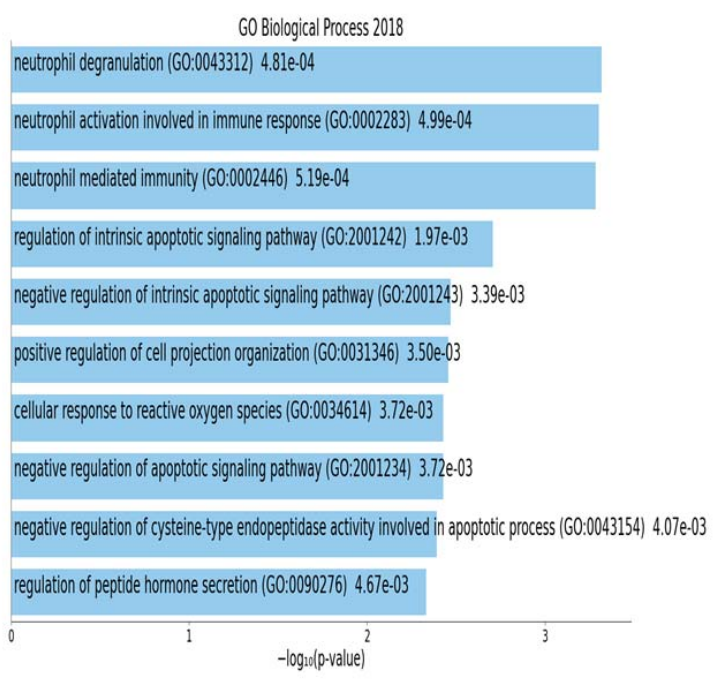

(a)

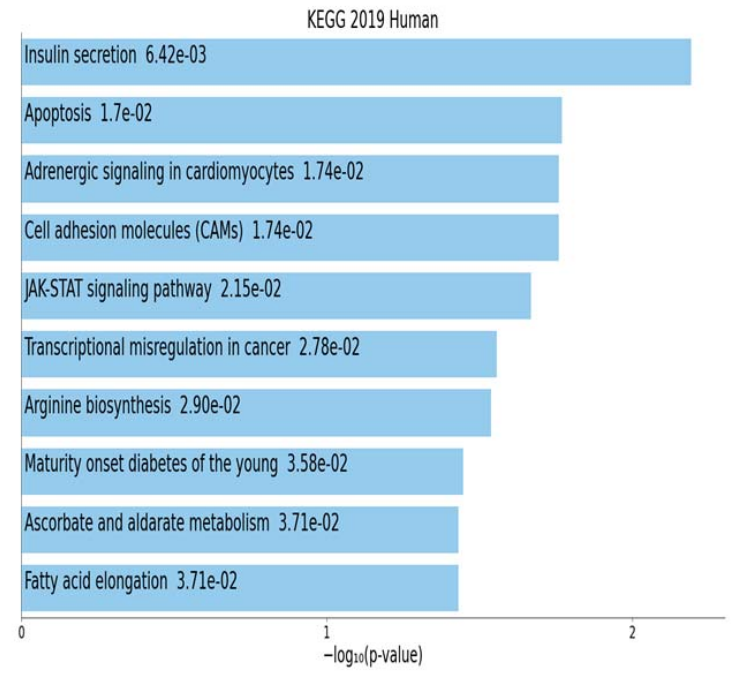

(b)

Figure 13: Downstream analyses of hub genes $(n=28)$ associated with type 2 diabetes in different tissues of human adults: (a) GO biological processes (b) KEGG pathways. 
COVID-19 Related Gene Sets SARS Perturbation Down Genes Mouse Lung from GSE19137:GPL1261:2 *2.11e-05

Up-regulated by SARS-COV-2 in NHBE from GSE147507 4.91e-03

Up-regulated by SARS-COV-2 in pancreatic organoids from GSE151803 4.91e-03

SARS perturbation Down Genes airway epithelium (HAE) from GSE47961:GPL6480:2 5.84e-03

SARS perturbation Up Genes PBMCS GDS1028:GPL201 6.87e-03

SARS-CoV-2/Human Interactome Gene Set from Guzzi 7.32e-03

SARS Perturbation Up Genes Mouse Lung from GSE19137:GPL1261:5 7.63e-03

SARS Perturbation Up Genes Mouse Lung from GSE68820:GPL7202:4 1.33e-02

SARS Perturbation Up Genes Mouse Lung from GSE19137:GPL1261:3 1.42e-02

Down-regulated by IAV-infection in mouse spleen $2.51 \mathrm{e}-02$

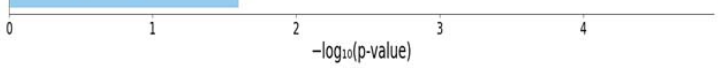

(a)

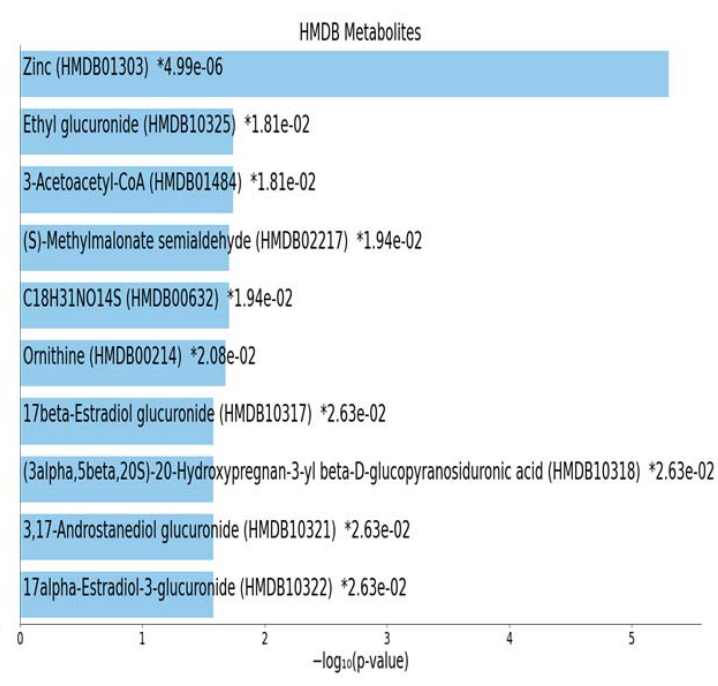

(b)

Figure 14: Downstream analyses of hub genes $(n=28)$ associated with type 2 diabetes in different tissues of human adults: (a) COVID-19 related gene sets (b) HMDB metabolites.

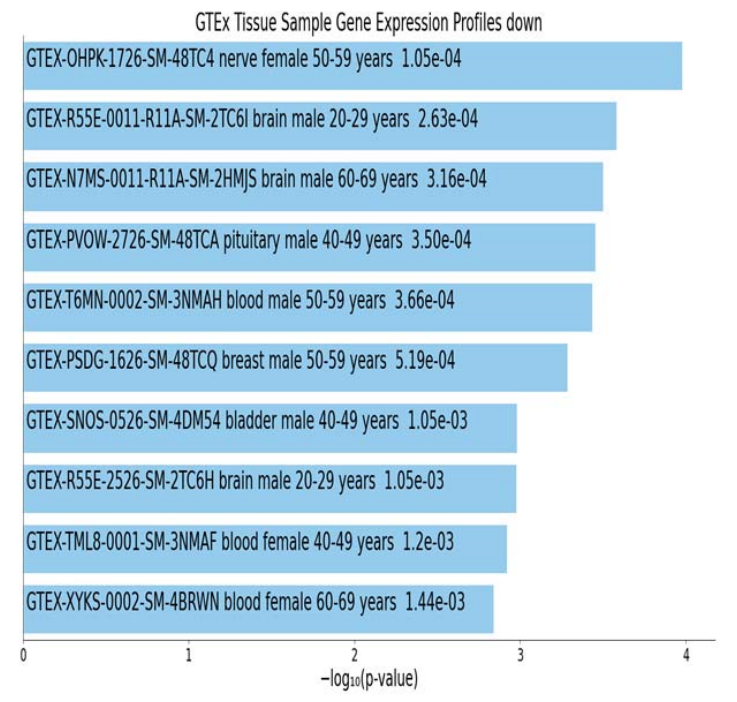

(a)

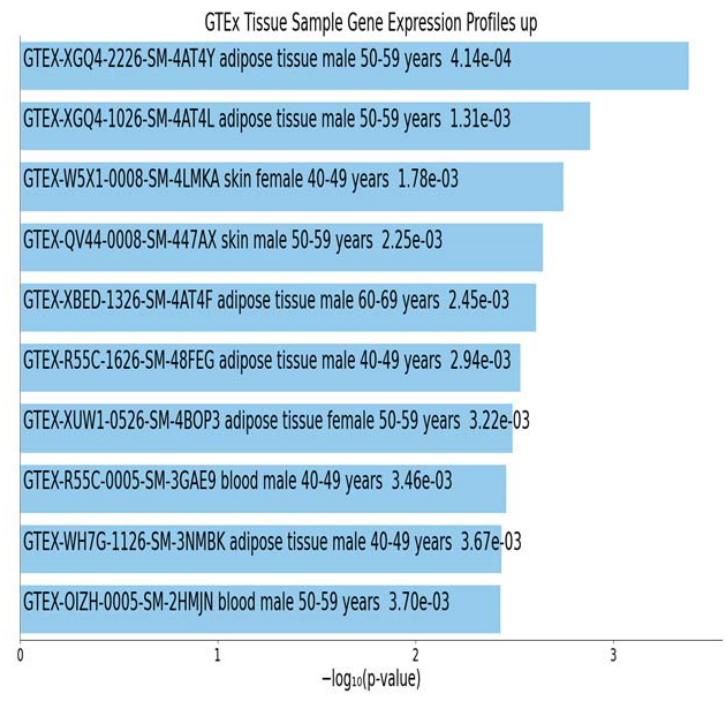

(b)

Figure 15: Downstream analyses of hub genes $(n=28)$ associated with type 2 diabetes in different tissues of human adults: (a) GTEx tissue sample gene expression profiles down. (b) GTEx tissue sample gene expression profiles up. 